\title{
Petrology, geochemistry and tectonic settings of the mafic dikes and sills associated with the evolution of the Proterozoic Cuddapah Basin of south India
}

\author{
Nilanjan Chatterjee ${ }^{1}$ And Somdev BhattacharjI ${ }^{2}$ \\ ${ }^{1}$ Department of Earth, Atmospheric and Planetary Sciences, Massachusetts Institute of Technology, \\ Cambridge, Massachusetts 02139, U.S.A. \\ ${ }^{2}$ Department of Geology, Brooklyn College, City University of New York, Brooklyn, New York 11210, \\ U.S.A.
}

In this article we summarize the petrological, geochemical and tectonic processes involved in the evolution of the Proterozoic intracratonic Cuddapah basin. We use new and available ages of Cuddapah igneous rocks, together with field, stratigraphic, geophysical and other criteria, to arrive at a plausible model for the timing of these processes during basin evolution. We present petrological and geochronological evidence of dike emplacement along preferred lineament directions around the basin in response to stresses, which may have been responsible for the evolution of the basin itself. Basaltic dike intrusion started on the south Indian shield around $2400 \mathrm{Ma}$ and continued throughout the Cuddapah basin evolution and sedimentation. A deep mantle perturbation, currently manifested by a lopolithic cupola-like intrusion under the southwestern part of the basin, may have occurred at the onset of basin evolution and played an important role in its development. Paleomagnetic, gravity and geochronological evidence indicates that it was a constant thermal source responsible for dike and sill emplacement between 1500 and $1200 \mathrm{Ma}$ both inside and outside the basin. Lineament reactivation in the NW-SE and NE-SW directions, in response to the mantle perturbation, intensified between 1400 and $1200 \mathrm{Ma}$, leading to the emplacement of several cross cutting dikes.

$\mathrm{Fe}-\mathrm{Mg}$ partition coefficients of olivine and augite and Ca-Na partition coefficient of plagioclase, calculated from the composition of these minerals and bulk composition of their host rocks, indicate that the dikes outside the Cuddapah basin are cumulates. The contemporary dikes may be related by fractional crystallization as indicated by a positive correlation between their plagioclase Ca\# (atomic $\mathrm{Ca} /[\mathrm{Ca}+\mathrm{Na}]$ ) and augite $\mathrm{Mg} \#$ (atomic $\mathrm{Mg} /[\mathrm{Mg}+\mathrm{Fe}]$ ). A few NW-SE and NE-SW cross cutting dikes of the period between 1400 and $1200 \mathrm{Ma}$, preserve petrographic evidence of episodic magmatic intrusive activity along preferred directions. Petrological reasoning indicates that a magmatic liquid reacted with a set of cross cutting dikes, intruding into one that was already solidified and altering the composition of the magma that produced the other dike.

The Cuddapah basin tholeiites may be related by fractional crystallization at $5 \mathrm{~kb}$ and 1019 $1154^{\circ} \mathrm{C}$, which occurred in the lopolithic cupola near the southwestern margin of the basin. Xenolith bearing picrites, which occur near the periphery of the cupola, originated by the accumulation of xenoliths in the tholeiites. This is indicated by the composition of the olivine in the xenoliths $\left(\mathrm{Fo}_{78.7-81.9}\right)$, which are closely similar to calculated olivine compositions $\left(\mathrm{Fo}_{77.8-78.3}\right)$ in equilibrium with the tholeiites under the same $P-T$ conditions. It is inferred that fractionation in the cupola resulted in crystals settling on its walls. Hence, the xenolith-bearing sills occur at the periphery of the lopolithic body.

Keywords. Cuddapah; proterozoic; basalt; geochemistry; mafic dike; mafic sill; petrology.

Proc. Indian Acad. Sci. (Earth Planet. Sci.), 110, No. 4, December 2001, pp. 433-453

(C) Printed in India. 
The tholeiites both inside and outside the basin are enriched in incompatible elements compared to mid oceanic ridge basalts. The $\mathrm{Ba}, \mathrm{Rb}$ and $\mathrm{K}$ contents of the Cuddapah and other Proterozoic Gondwana tholeiites indicate that a widespread metasomatic enrichment of the mantle source may have occurred between $\sim 2.9$ and $\sim 2.7 \mathrm{Ga}$. There may be local heterogeneity in the source of the Cuddapah tholeiites as indicated by different $\mathrm{Ba} / \mathrm{Rb}, \mathrm{Ti} / \mathrm{Zr}, \mathrm{Ti} / \mathrm{Y}, \mathrm{Zr} / \mathrm{Nb}$ and $\mathrm{Y} / \mathrm{Nb}$ in samples inside and outside the basin. Large-scale differences such as the low $\mathrm{P}_{2} \mathrm{O}_{5}-\mathrm{TiO}_{2}$ and high $\mathrm{P}_{2} \mathrm{O}_{5}-\mathrm{TiO}_{2}$ basaltic domains of the Jurassic Gondwana basalts, however, did not exist during the Proterozoic time period under consideration.

Although we are beginning to understand the tectono-magmatic processes involved in the evolution of the Cuddapah basin, much work remains to be done to obtain a complete picture. Future research in the Cuddapah basin should focus on obtaining accurate ages of the igneous rocks associated with the evolution of the basin.

\section{Introduction}

Igneous rocks associated with intracratonic Proterozoic basins play a vital role in establishing their evolutionary history. Dikes and dike swarms provide evidence of the state of stress of the lithosphere, nature of crustal extension and rifting during basin evolution. Ages of dikes, sills and flows help in stratigraphic correlation as well as in providing timing constraints on processes involved in basin evolution. The igneous rocks in and around the Cuddapah basin of south India present a unique opportunity to study their significance with respect to the evolution of the basin.

The Cuddapah basin is superposed on Archean gneisses and granites of the Dharwar Craton, and is the largest Proterozoic basin on the Indian peninsula covering an area of about $34,000 \mathrm{~km}^{2}$ (figure 1). It is situated between $13^{\circ} 15^{\prime} \mathrm{N}$ and $17^{\circ} 00^{\prime}$ $\mathrm{N}$ latitudes and $77^{\circ} 45^{\prime} \mathrm{E}$ and $80^{\circ} 15^{\prime} \mathrm{E}$ longitudes, convex westward and extends north to south over a crescent length of $440 \mathrm{~km}$ with a maximum width of $150 \mathrm{~km}$ east to west. The sediments in the basin consist of easterly low dipping $\left(10^{\circ}-15^{\circ}\right)$ alternating sequences of arenaceous, argillaceous and carbonate assemblages. The total estimated thickness of the sedimentary formations is of the order of $6.5 \mathrm{~km}$ (Murty 1979). In many cases, the sediments are interlayered with sills, tuffs and lava flows at different stratigraphic horizons. They are marked by unconformities and post-depositional folding and faulting. The maximum depth near the center of the basin, obtained from deep seismic sounding (DSS) profiles is $8-8.5 \mathrm{~km}$ (Kaila and Tewari 1983).

One of the most striking features in the Archean crust surrounding the Cuddapah basin is the occurrence of a large number of dikes and dike swarms (figure 1). Some of these dikes and dike swarms are arranged radially around the western and southern margins of the basin, whereas, others are aligned along the major NE-SW and NW-SE lineaments of south India (Bhattacharji 1987; Murty et al
1987). Petrological and geochronological studies of several cross cutting dikes show that these dikes may be related to lineament reactivation during the evolution of the Cuddapah basin.

The Cuddapah basin area is interesting from a global tectonic perspective since, tholeiitic and high- $\mathrm{Mg}$ dikes similar in age and composition to the Cuddapah tholeiites are also found in a section of east Antarctica, which was adjacent to the Cuddapah area during Proterozoic. It has long been recognized that the Enderby Land coast of east Antarctica fits well with the eastern coast of India (Smith and Hallam 1970). Reconstruction of Gondwanaland and Laurentia has reaffirmed that the Indian and East Antarctic shields were juxtaposed (figure 2) during middle to late Proterozoic (Johnson and Veevers 1984; Piper 1987; Dalziel 1991; Hoffman 1991).

\subsection{Thermal events and stratigraphy}

Phases of igneous activity, tectonic events and changes in the depositional environment associated with the Cuddapah stratigraphy have been well documented by Bhattacharji (1987). The Precambrian shield of India consists of a high grade metamorphic belt of charnokite-khondalite and migmatites, the Dharwar system of schists, greenstone and granites, and the Purana group consisting of the Proterozoic Cuddapah, Kurnool, Srisailam and Palnad sedimentary systems, together with the enclosing Peninsular Gneissic basement complex. The evolution of the Cuddapah basin is marked by cyclic heating and upliftment of the crust and a break in sedimentation followed by subsidence, gravity faulting and sedimentary deposition (Bhattacharji 1987).

The Cuddapah region of the south Indian shield experienced extensive igneous activity in the form of dike intrusion between 2400 and 2000 Ma, which may be considered a precursor to the Cuddapah basin evolution. A funnel-shaped intrusion in 


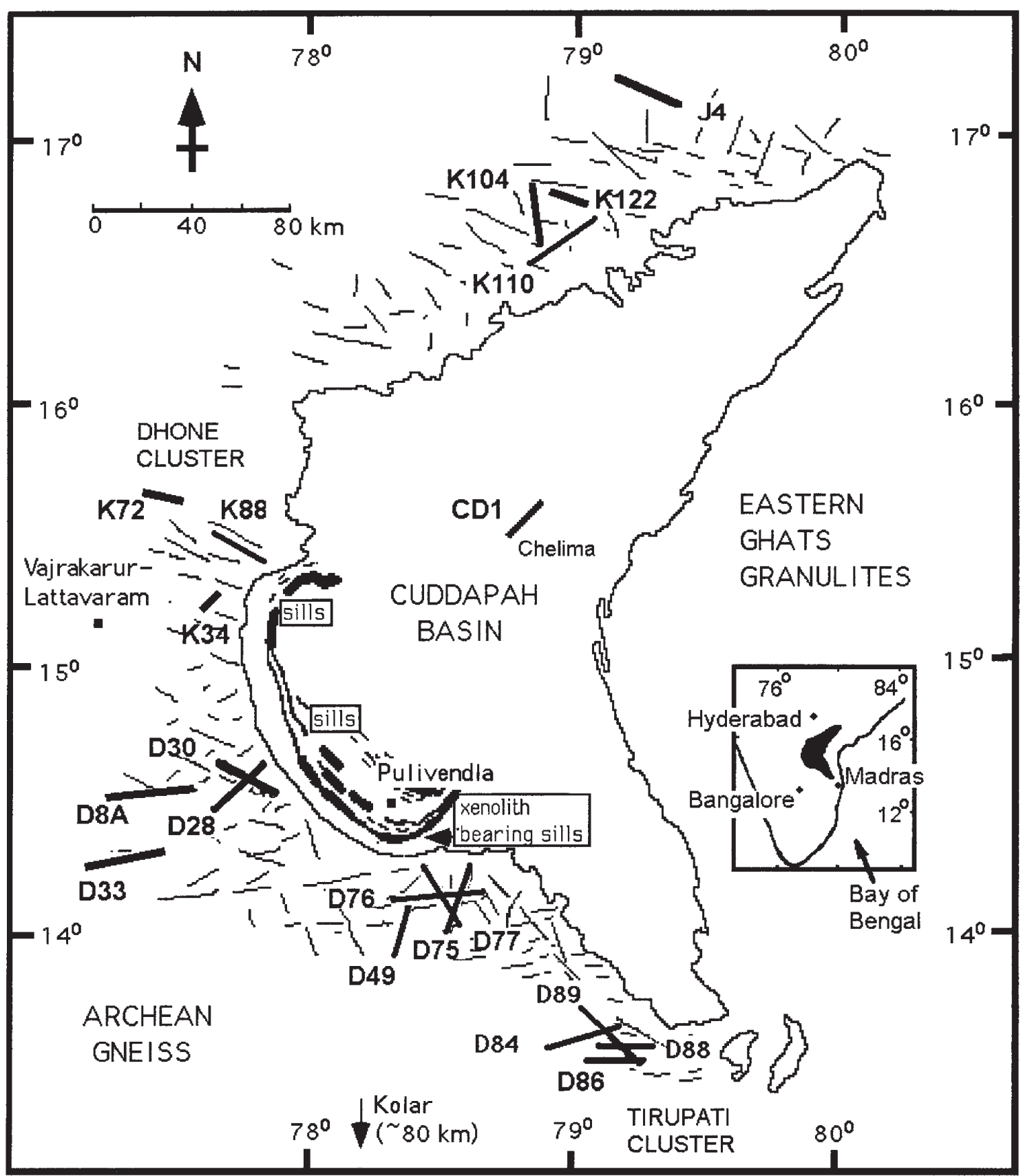

Figure 1. Map of Cuddapah basin showing location and orientation of mafic dikes around the basin. Important dikes studied in detail are shown in bold lines. Orientation of the dikes and dike swarms outside the basin (shown in thin lines) are from Murty et al. (1987). The inset shows the location of Cuddapah basin in the Indian subcontinent. Note the structural trends defined by the dikes.

the upper crust possibly occurred at the onset of basin evolution. This intrusion is manifested by a gravity-high in the southwestern region of the present day basin (Bhattacharji 1987). The resultant heating and upliftment of the crust was followed by cooling, subsidence and gravity faulting in the southwestern margin of the proto-basin, which created ideal conditions for the deposition of the Lower Cuddapah sediments. The Lower Cuddapah sequence, known as the Papaghni Group, consists of the Gulcheru quartzites and conglomerates and the Vempalle dolomites and shales. The Vem- palle dolomites and shales are interlayered with sills, tuffs and lava flows. The igneous activity produced crustal heating and upliftment, which led to a break in the depositional cycle. The overlying sequence, separated by a disconformity and known as the Chitravati (Cheyair) Group, consists of the Pulivendla quartzites, Tadpatri shales and dolomites and the Gondikota quartzites. The Tadpatri shales and dolomites contain many basaltic and picritic sills and lava flows. This extensive igneous activity again heated and uplifted the crust leading to another break in deposition. Subsidence, 


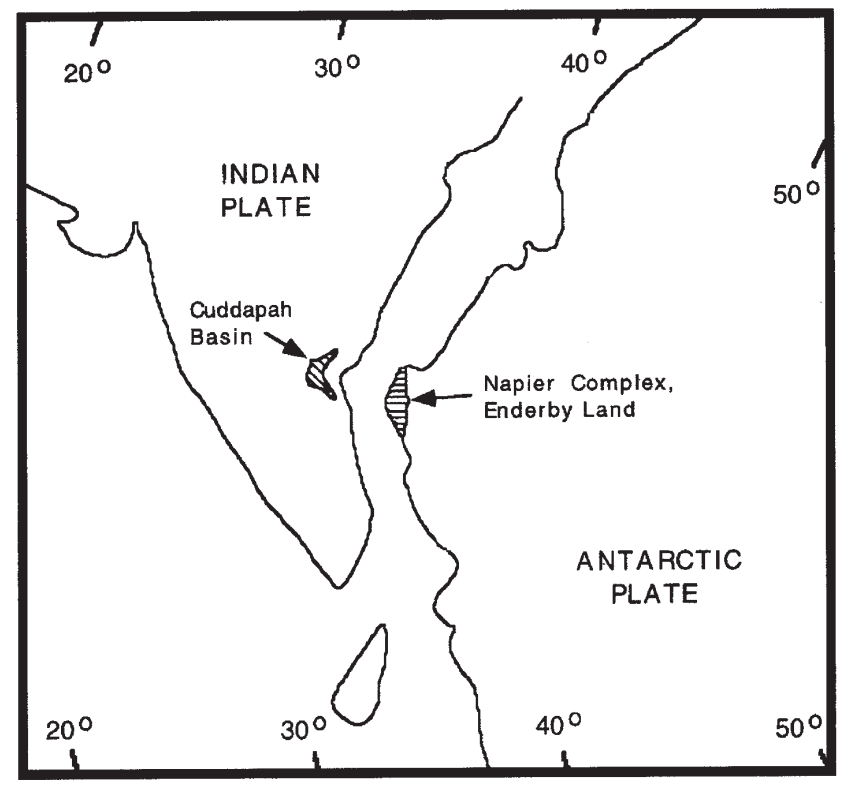

Figure 2. Schematic representation of a part of Gondwanaland showing locations of Napier Complex, Enderby Land (east Antarctica) and Cuddapah basin (south India) during late Proterozoic. This reconstruction, representing Gondwanaland more than $160 \mathrm{Ma}$ ago, is from Johnson and Veevers (1984) and is based on the fit of the $4 \mathrm{~km}$ isobath of the Indian and Antarctic coasts. The paleolatitudes are from paleomagnetic determinations of Embleton (1984).

flexuring and gravity faulting resulted in an eastward tilting and shifting of the center of sedimentary deposition toward east.

The overlying Nallamallai Group is separated from the Chitravati (Cheyair) Group by an angular unconformity. This group contains the Bairenkonda (Nagri) quartzites and the Cumbum shales and phyllites. Deposition of the Nallamallai Group was accompanied by extensive alkaline and acidic volcanic activity. In addition to the emplacement of alkaline syenite and granites within the basin, the Chelima lamproite dike near the center of the basin, the Kotakonda kimberlite outside the northwestern margin of the basin, and later, the kimberlite dikes west of the basin in the granite-granulite terrain near VajrakarurLattavaram intruded. This resulted in localized crustal heating, domal upwarps and break in deposition followed by subsidence. The depositional areas shifted as gravity induced block faulting occurred, producing the isolated sub-basins of Srisailam in the north and Palnad in the northeast.

An unconformity marks the upper boundary of the Nallamalai Group, above which sediments were deposited in the Srisailam sub-basin in the north, and Palnad sub-basin in the northeast of the main Cuddapah basin. The post-Kurnool period was marked by deformation at the eastern margin and late-stage igneous activity outside the western margin in the form of granophyre dike intrusion.

\subsection{Geophysical characteristics}

The Cuddapah basin and its surroundings have been extensively studied through gravity, magnetic, deep-seismic sounding, electrical resistivity, heat flow and telluric methods. These studies reveal the depth of the basin, crustal structure, areas of mantle upwelling, igneous intrusions, deep faults and lineaments in this region (Balakrishna 1979; Kaila et al 1979; Sankaranarayan et al 1979; Rao et al 1979; Balakrishna et al 1983; Kaila and Tewari 1983). Bouguer gravity anomalies (Balakrishna 1979) and DSS profiles (Kaila et al 1979) show the Moho boundary at an average depth of $38-40 \mathrm{~km}$, with thinning of the crust toward the east. Two DSS profiles across the basin (Kaila and Tewari 1983) indicate that the basement depth is highly variable within the basin, with a maximum depth of 8.0 to $8.5 \mathrm{~km}$ in the central axial region. DSS profiles also show that the basement crust is faulted into several blocks underneath the basin. Some of these blocks are upthrown, and some are downthrown, more or less in a step-like fashion towards the east. Many of these deep-seated faults extend to the crust-mantle boundary (Kaila et al 1979), some to a depth of $40 \mathrm{~km}$ or more near the eastern margin. Interestingly, tectonic configurations and several igneous intrusives (e.g., Chelima lamproite dikes) occur close to the postulated deep faults in the east-central area of the basin, indicating a causal relationship between the basement configuration and the emplacement of deep mantlederived igneous rocks within the basin.

A broad gravity low (approximately -23 mgals) with a few gravity highs occurs across the basin. The detailed gravity anomaly map of the Cuddapah basin and its surroundings (Balakrishna 1979; Grant 1983) shows an elongated closure of positive anomaly ( +60 mgals) covering an area approximately $80 \times 50 \mathrm{~km}$ in the southwestern part of the basin. This is also a terrain of extensive mafic and ultramafic sills and flows, and mafic and felsic tuffs within the basin. Extensive radial and some arcconcentric dolerite-gabbro dikes and dike swarms occur in the immediate vicinity outside the basin (figure 1). This positive gravity anomaly is situated almost concentrically within a very broad, almost circular gravity low. The shape of this anomaly indicates that it is caused by an oval-shaped, shallow crustal lopolithic intrusion with a system of thin feeder dikes (Grant 1983).

The estimated densities of this anomalous mass and the central feeder dike are $3.0-3.1 \mathrm{gm} . \mathrm{cm}^{-3}$ and $3.2 \mathrm{gm} . \mathrm{cm}^{-3}$ respectively. They correspond to olivine-gabbro or picrite in the main funnel and feldspathic peridotite or troctolite for the feeder zone. The origin of this anomalous high density body can be ascribed to the formation of a 
lopolithic or a funnel-shaped magma cupola in the upper crust due to an asthenospheric upwelling at the southwestern part of the basin (figure 1). The correspondence of this high density mantle mass with the picrite and olivine- gabbro-dolerite sills, and with some of the dike swarms of similar chemistry suggests a common source and a close genetic relationship among them (Murthy et al 1985). Paleomagnetic studies (Balakrishna et al 1972; Kumar and Bhalla 1983; Hargraves and Bhalla 1983) show three different intensities of magnetization and polarities for several dikes at the western margin, indicating three different episodes of dike activity. This may also indicate reactivation of preexisting planes of weakness and/or poorly healed fractures in the brittle crust during dike intrusive activities and crustal dilation.

\subsection{Tectonic evolution}

The variety of structural settings and tectonomagmatic events associated with intracratonic basins makes it difficult to arrive at a single satisfactory mechanism for sedimentary basin evolution (Haxby et al 1976; Bott 1978; McKenzie 1978; Steckler and Watts 1978; Artyushkov et al 1980; Sleep et al 1980, etc.). Some basins are associated with early igneous activity and normal faulting, while others are not. Some are accompanied by igneous activity prior to basin formation, while others exhibit no apparent igneous activity during the whole history of sedimentary accumulation or subsequent to formation, and still others appear to have been affected only by late-phase magmatism. The role of mantle upwelling and magmatism, lineament reactivation and crustal uplift in the evolution of the Cuddapah basin can be established with some degree of certainty (Bhattacharji and Singh 1984; Bhattacharji 1986, 1987; Murty et al 1987; Chatterjee and Bhattacharji 1998).

The Cuddapah basin has an extremely complex evolutionary history. It experienced several cycles of uplift and subsidence, episodic magmatism prior to and during the sedimentary accumulation, and syn- to post-depositional deformation. The sediment types, their structural and lithofacies changes indicate that the deposition of the basin sediments occurred at the margin of geosynclinal shelf, primarily on a platform which experienced marine transgressions and regressions as well as oscillations of the basin floor, and four cycles of basin upliftment and subsidence. Each cycle of upliftment was preceded by igneous activity and followed by erosion, and then slow to rapid subsidence of the basin (Bhattacharji 1981). Bhattacharji and Singh (1984) found that a mechanical (Airy type) subsidence model for the Cuddapah basin with only isostatic subsidence due to sedimentary accumulations alone does not adequately explain the depths of the basin floor. They presented a thermomechanical model, which includes both sedimentation and a thermal-driving load to account for the maximum depth and explain most realistically the geological and geophysical features of the Cuddapah basin.

Apart from simple sedimentary loading, isostatic subsidence of a basin can also occur by thermal cooling and contraction of the crust after igneous intrusive activity and the subsequent increase in density and sinking of the lithosphere (Beloussov 1960; Sheridan 1969). Watts and Ryan (1976) have shown that the 'driving load' for Atlantic-type continental margins is thermal contraction (cooling). Included in this type of 'driving load' for basin subsidence are also increases in the density of the lower crust by metamorphism or phase transformation (Falvey 1974; Haxby et al 1976; Artyushkov et al 1980). The computed isostatic subsidence of the basin floor by elastic flexuring of the basement crust is of the order of 6.5 to $6.7 \mathrm{~km}$, which accounts for the estimated thickness of the total column of sedimentary formations and emplaced igneous materials still preserved in the basin. However, it is not commensurate with the maximum basin depth of 8 to $8.5 \mathrm{~km}$ at the center of the basin estimated from deep seismic sounding profiles by Kaila and Tewari (1983). This additional 1.5 to $2.0 \mathrm{~km}$ depression may be the result of isostatic subsidence produced by a thermal 'driving load' (Watts and Ryan 1976). The 'driving load' for the initial subsidence of the Cuddapah basin appears to underlie the platform of the granite gneiss-greenstone belt crust near the southwestern margin, an area of positive gravity anomaly attributed to an asthenospheric upwelling. Thermal cooling and contraction of the emplaced highdensity mantle material in the upper crust may have produced the initial basin subsidence. Gravity faulting along lineaments in the basement crust at the basin's margin during thermal cooling of the emplaced mantle mass may have produced some subsidence of the basin floor (Bhattacharji and Singh 1984; Bhattacharji 1987).

\subsection{Lineaments around the Cuddapah basin}

Sundaram et al (1964) have argued that the major NW-SE structural trend and lineaments in the Dharwar belt controlled the epiorogenic adjustments and the development of sedimentary basins on the peninsular Indian shield. A careful examination of the relative positions and shapes of the Proterozoic basins on the south Indian shield shows that their development was controlled by reactivation of the NW-SE and NE-SW trending linea- 


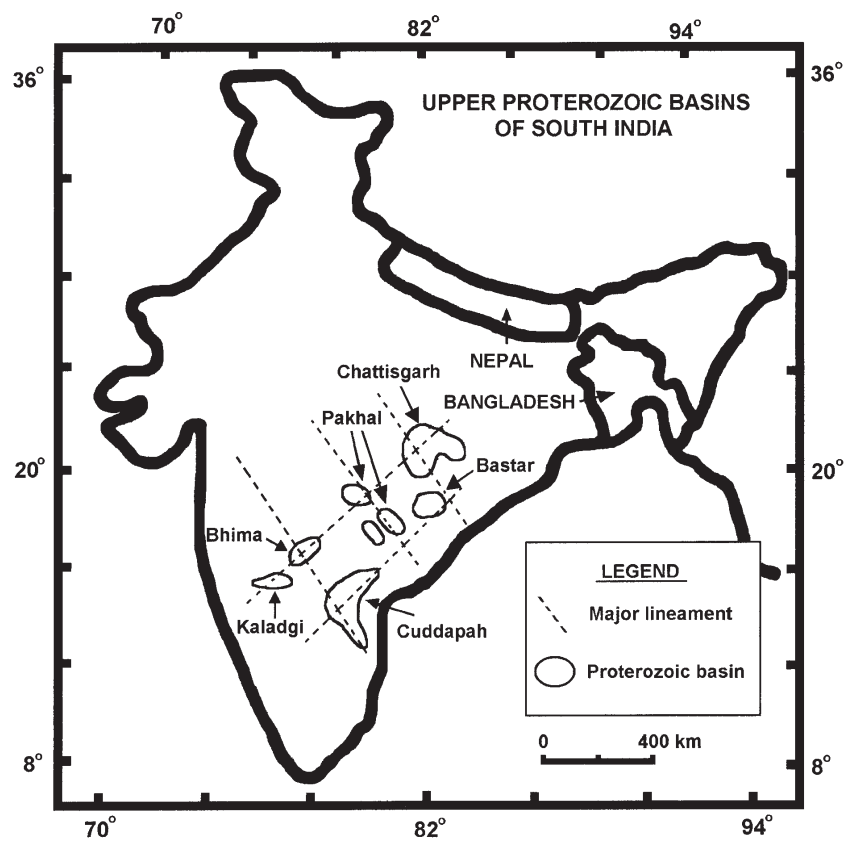

Figure 3. The orientation of two major lineaments (NW-SE and NE-SW) in the Precambrian crust of the south Indian shield and its apparent control of the development of Proterozoic basins (adopted from Bhattacharji 1987). Note the arcuate to crescent shape of the Cuddapah basin, which appears to be controlled by the superposition of narrow rectilinear to oval-shaped shallow sub-basins along the NE-SW lineament direction over the oval-shaped Proto-Cuddapah basin along NW-SE to N-S lineament direction. The crescent shape was accentuated by post-depositional E-W tectonic compression.

ments (figure 3). The prominent rhombic aeromagnetic linears along the same trends at the western margin of the Cuddapah basin reaffirm this conclusion and suggest a possible E-W tectonic compression and reactivation of these lineaments (Bhattacharji 1987; Murty et al 1987).

A lineament generally represents a prominent zone of weakness: a deep fracture or fault manifested as widely spaced and sharp linear planes with specific aerial trends. Field, aerial and landsat photographs, and aeromagnetic anomaly maps show that the major lineament trends on the peninsular Indian shield around the Cuddapah basin are NW-SE to WNW-ESE, NE-SW to ENE-WSW (Murty et al 1987). Some of these trends correspond to major faults, and others correspond to major dike systems. The major orientation of the extensive linear dikes and dike swarms around the Cuddapah basin are E-W, NW-SE to WNW-ESE, NE-SW to ENE-WSW, and N-S (Murty et al 1987 and figure 1). As the dike emplacements represent the dilation of the upper crust by magma intrusion with extensional fracturing or faulting, NW-SE to WNW-ESE and NE-SW to ENE-WSW dikes and dike swarms indicate the possible reactivation of lineaments or deep faults in the basement crust (Bhattacharji 1987).
Field evidence suggests that the ENE-WSW linear trend is a major tectonic break zone within the Archean crust, which traverses the Cuddapah basin and terminates at the thrust belt on its eastern margin. The NW-SE fracture zone also traverses the western margin of the Cuddapah basin and is a part of the basement beneath the basin itself. This is also the major structural trend of the Dharwar belt. A prominent WNW-ESE linear fault crosses the area near the kimberlite pipes at the southwestern part of the basin (between $14^{\circ}$ and $\left.15^{\circ} \mathrm{N}\right)$. The intersections of the WNW-ESE lineaments with the ENE-WSW lineaments or deep faults appear to be the sites for some igneous intrusive and effusive activities. These intersections are marked by ore-mineralization (e.g., barite) within the southwestern part of the basin and outside the basin at Vajrakarur-Lattavaram, where deep mantle derived kimberlites from a depth of approximately 120 to $180 \mathrm{~km}$ are found (Ganguly and Bhattacharya 1987; Bhattacharji 1987).

\section{Basaltic igneous rocks}

The dikes intruding the Archean crust around the Cuddapah basin are composed of tholeiites and alkali basalts and their differentiates. There are dikes of gabbro, amphibolite (metamorphosed gabbro), kimberlite, granophyre and syenite. But the majority of the dikes are basalt-dolerites. The largest concentration of mafic dikes occur as E-W clusters at the southern end of the basin and are known as the Tirupati dike swarm or cluster (figure 1). They extend westward over long distances across the greenstone-granite gneiss terrain. Many of the oldest dikes of this area precede the formation and evolution of the Cuddapah basin. But there are many younger $\mathrm{E}-\mathrm{W}$ trending dikes in this region, which were emplaced during the formation and evolution of the basin (Murty et al 1987). These $\mathrm{E}-\mathrm{W}$ trending dikes at the southern end of the basin were correlated with the $\mathrm{E}-\mathrm{W}$ trending gravity high in this region by Balakrishna et al (1984). A few NW-SE trending dikes are also present which cut across some of these dikes (figure 1).

The second largest concentration of mafic dikes occurring as a dike swarm near Dhone is known as the Dhone cluster (Murty et al 1987, figure 1). The dikes in this dike swarm trend primarily NW-SE, paralleling the major NW-SE lineament trend of the Dharwar Archean crust. These dikes constitute a part of the radial dike system surrounding the Cuddapah basin (Bhattacharji 1986). A few NESW trending dikes are also present in this area which cut across some of the NW-SE trending dikes (figure 1). 
At the western and southwestern margins of the Cuddapah basin, the Archean crust is intruded by numerous dikes and dike clusters. Many of these dikes occur as isolated dikes trending parallel to the NW-SE and NE-SW lineament trends for over $150 \mathrm{~km}$ or more. In general, a majority of the dikes are short and segmented and often occur in en echelon pattern. The width of the majority of the dikes range from 10 to $50 \mathrm{~m}$, but there are a number of dikes as wide as 70 to $80 \mathrm{~m}$.

Inside the basin, the lower Cuddapah Vempalle and Tadpatri formations contain many tholeiitic sills, lava flows and tuffs. Along the southwestern margin of the basin occurs a group of sills that are concentric with the arcuate margin of the basin. Near Pulivendla, some of the sills contain gabbroic xenoliths and accumulations of mafic xenocrysts. These xenolith bearing arc-concentric sills constitute a minor, but petrologically significant element of the Tadpatri formation near the southwestern margin of the basin (figure 1). Various workers (e.g., Murthy 1964; Rao and Rao 1964, Sinha and Krishna Rao 1968; Somayajulu and Singhal 1968; Dasgupta 1986) have described these sills as picritic. Dikes are absent inside the basin with the exception of the Chelima lamproites near the center of the basin (figure 1). The xenolith bearing area of the sills coincides with the gravity high attributed to the lopolithic intrusion beneath the southeastern part of the basin (Grant 1983, Murty et al 1987).

Counterparts of the Cuddapah basin tholeiites are found in east Antarctica (figure 2). A group of doleritic tholeiite dikes occurring in the Napier Complex of east Antarctica (the Amundsen dikes, Sheraton and Black 1981) are especially interesting since, they are of Mid-Proterozoic age and are similar in chemistry to the Cuddapah basin tholeiites.

\section{Geochronology}

In tables $1(\mathrm{~A})$ and $1(\mathrm{~B})$, we present radiometric ages of whole rock samples determined in this study and previously determined ages by other workers. In figure 4, we show apparent integrated ${ }^{40} \mathrm{Ar}^{-39} \mathrm{Ar}$ ages of three dike samples plotted against fractions of released ${ }^{39} \mathrm{Ar}$. These samples did not show welldefined plateau ages. The gas fractions were added over the imperfect plateau region to arrive at an integrated age of the whole rock sample. Uncertainties in these ages are estimated at the $1 \sigma$ confidence level. For K-Ar whole rock age determination, all samples were crushed to $-80 /+200$ mesh and treated with dilute $\mathrm{HF}$ and $\mathrm{HNO}_{3}$ to remove alterations. For each dike, two whole rock samples were analyzed. The uncertainties for the K-Ar apparent ages are estimated at the $2 \sigma$ confidence level.

Ages of important igneous bodies are shown in table $1(\mathrm{~A})$. The oldest tholeiite dikes on the south Indian shield (Bidadi-Harohalli area, about $100 \mathrm{~km}$ SW of Kolar) are 2369 $\pm 246 \mathrm{Ma}$ old (Rb-Sr age determined by Ikramuddin and Stueber 1976; recalculated by Collerson and Sheraton 1986) with an initial ${ }^{87} \mathrm{Sr} /{ }^{86} \mathrm{Sr}$ of $0.7012 \pm 0.0010$. However, the oldest dike that may be associated with the initiation of the Cuddapah basin is the $1879 \pm 5 \mathrm{Ma}$ old, E-W trending dike southwest of the basin, as dated by the ${ }^{40} \mathrm{Ar}-{ }^{39} \mathrm{Ar}$ method. A recent $\mathrm{Rb}-\mathrm{Sr}$ isochron age of $\sim 1900 \mathrm{Ma}$ of gabbroic dike swarms has been determined by Kumar et al (1990) in the Dharwar craton intruding $\sim 2100$ Ma old Proterozoic granites. This supports a thermal event and crustal dilation with dike intrusive activity at the SW margin of the present day Cuddapah basin where early sedimentation in the basin occurred (Bhattacharji 1987; Bhattacharji and Singh 1984). The age of the oldest mafic flows inside the basin is debatable, but they are probably contemporary to the oldest $\mathrm{E}-\mathrm{W}$ dike immediately outside the basin. Although a K-Ar age of $1841 \pm 71 \mathrm{Ma}$ of a Vempalle lava flow has been determined by Murty et al (1987), a recent Rb-Sr age of a Pulivendla sill in the Chitravati group by Bhaskar Rao et al (1995) yields an identical age of $1817 \pm 24 \mathrm{Ma}$. The Tadpatri formation (Chitravati Group) consists of $\sim 4600 \mathrm{~m}$ thick sediments and overlies an unconformity between the Vempalle and Tadpatri formations. Thus, it is likely that the Vempalle formation is older than $1841 \pm 71 \mathrm{Ma}$. Crawford and Compston (1973) determined an $\mathrm{Rb}-\mathrm{Sr}$ age of $1550 \pm 147 \mathrm{Ma}$ by with an initial ${ }^{87} \mathrm{Sr} /{ }^{86} \mathrm{Sr}$ of $0.7044 \pm 0014$ (recalculated by Collerson and Sheraton 1986) of a mafic flow from the lowermost Vempalle sedimentary sequence in the western side of the basin. This age is improbable, as the samples were poorly radiogenic and the isochron may have been poorly defined (Bhaskar Rao et al 1995). Crawford and Compston (1973), however, suggested that volcanism in the Cuddapah basin may have started as early as $\sim 1700 \mathrm{Ma}$.

While dike emplacement started possibly before the initiation of basin formation, it continued intermittently throughout and after sedimentary deposition in the basin (Kumar et al 1988). The Chelima lamproite dikes, which intrude the Cumbum formation of the upper Nallamalai Group near the center of the basin, place an upper bound on the age of the Cuddapah sequence at approximately $1400 \mathrm{Ma}$. This is indicated by a ${ }^{40} \mathrm{Ar}-{ }^{39} \mathrm{Ar}$ plateau age determination of $1417.8 \pm$ 8.2 Ma (Chalapathi Rao et al 1999, see table 1A) and supported by K-Ar ages of $1371 \pm 45 \mathrm{Ma}$ (Murty et al 1987) and $1363 \pm 48 \mathrm{Ma}$ (Chala- 
Table 1(A). Whole rock age of important igneous bodies in and around the Cuddapah basin, south India.

\begin{tabular}{|c|c|c|c|c|}
\hline & Location & Age & Method & Source \\
\hline Mafic dike & Bidadi-Harholli, west of Kolar & $2369 \pm 246$ & $\mathrm{Rb}-\mathrm{Sr}$ & $\begin{array}{l}\text { Ikramuddin and Stueber } 1976 \text {, } \\
\text { Collerson and Sheraton } 1986 .\end{array}$ \\
\hline $\begin{array}{l}\text { Mafic dike } \\
\text { trending } \mathrm{E}-\mathrm{W}\end{array}$ & Southwest of basin & $1879 \pm 5$ & ${ }^{40} \mathrm{Ar}-{ }^{39} \mathrm{Ar}$ & This study. \\
\hline Mafic flow & $\begin{array}{l}\text { Lower part of lower Cuddapah, } \\
\text { Vempalle formation, western part of } \\
\text { basin }\end{array}$ & $1841 \pm 71$ & $\mathrm{~K}-\mathrm{Ar}$ & Murty et al 1987. \\
\hline Mafic sill & $\begin{array}{l}\text { Upper part of lower Cuddapah, } \\
\text { Pulivendla formation, western part } \\
\text { of basin }\end{array}$ & $1817 \pm 24$ & $\mathrm{Rb}-\mathrm{Sr}$ & Bhaskar Rao et al 1995. \\
\hline Mafic flow & $\begin{array}{l}\text { Lower part of lower Cuddapah, } \\
\text { Vempalle formation, westerm part } \\
\text { of basin }\end{array}$ & $1550 \pm 147$ & $\mathrm{Rb}-\mathrm{Sr}$ & $\begin{array}{l}\text { Crawford and Compston 1973, } \\
\text { Collerson and Sheraton } 1986 .\end{array}$ \\
\hline $\begin{array}{l}\text { Lamproite dike } \\
\text { trending NE- } \\
\text { SW }\end{array}$ & $\begin{array}{l}\text { Upper Cuddapah, Cumbum forma- } \\
\text { tion of Nallamalai group, center of } \\
\text { basin near Chelima }\end{array}$ & $1418 \pm 8$ & ${ }^{40} \mathrm{Ar}-{ }^{39} \mathrm{Ar}$ & Chalapathi Rao et al 1999 \\
\hline $\begin{array}{l}\text { Lamproite dike } \\
\text { trending NE- } \\
\text { SW }\end{array}$ & $\begin{array}{l}\text { Upper Cuddapah, Cumbum forma- } \\
\text { tion of Nallamalai group, center of } \\
\text { basin near Chelima }\end{array}$ & $1371 \pm 45$ & $\mathrm{~K}-\mathrm{Ar}$ & Murty et al 1987. \\
\hline $\begin{array}{l}\text { Arc-concentric, } \\
\text { mafic sill }\end{array}$ & $\begin{array}{l}\text { Upper part of lower Cuddapah, } \\
\text { Tadpatri formation, western part of } \\
\text { basin }\end{array}$ & $958 \pm 29$ & $\mathrm{~K}-\mathrm{Ar}$ & Murty et al 1987. \\
\hline $\begin{array}{l}\text { Arc-concentric, } \\
\text { mafic sill }\end{array}$ & $\begin{array}{l}\text { Upper part of lower Cuddapah, } \\
\text { Tadpatri formation, western part of } \\
\text { basin }\end{array}$ & $809 \pm 29$ & $\mathrm{~K}-\mathrm{Ar}$ & Murty et al 1987. \\
\hline $\begin{array}{l}\text { Granophyre } \\
\text { dike trending } \\
\text { NE-SW }\end{array}$ & Southwest of basin & $646 \pm 23$ & $\mathrm{~K}-\mathrm{Ar}$ & Dayal and Padmakumari 1987. \\
\hline
\end{tabular}

pathi Rao et al 1996). If these ages are true indications, the entire Cuddapah sequence was deposited between 1850 and $1400 \mathrm{Ma}$ approximately, within the error limits of the age determinations.

Igneous intrusion continued both outside and inside the basin after sedimentation ceased. The youngest dike (granophyre) outside the basin dates back to $646 \pm 23 \mathrm{Ma}$ (K-Ar age, Dayal and Padmakumari 1985). Within the basin, some arcconcentric sills in the Tadpatri formation of the Chitravati group (upper part of the lower Cuddapah sequence) were emplaced between $958 \pm 29 \mathrm{Ma}$ and $809 \pm 29 \mathrm{Ma}$ as determined by the K-Ar method (Murty et al 1987, see table 1A). These sills are too young to be directly related to the mantle perturbation and must represent a different episode of magmatic activity. If these ages are correct, igneous activity in the basin must have continued intermittently over a period of 900-1000 Ma. However, in view of the contradictions in the ages of the lower Cuddapah igneous rocks as discussed above, further geochronological studies supported by paleomagnetic data are clearly required to determine the duration of thermal events and their tectonomagmatic significance in the evolution of the Cuddapah basin.
Interestingly, the high-Mg and tholeiitic dikes of Napier Complex, east Antarctica (Sheraton and Black 1981) show a temporal proximity and isotopic similarity to the Dharwar dikes. The high-Mg dikes of east Antarctica are $2350 \pm 48 \mathrm{Ma}$ old with an initial ${ }^{87} \mathrm{Sr} /{ }^{86} \mathrm{Sr}$ ratio of $0.7020 \pm 0.0008$ (Sheraton and Black 1981), and comparable to the dikes of Bidadi-Harohalli area of south India (Ikramuddin and Stueber 1976). The tholeiitic Amundsen dikes of east Antarctica, which are $1190 \pm 200 \mathrm{Ma}$ old with an initial ${ }^{87} \mathrm{Sr} /{ }^{86} \mathrm{Sr}$ ratio of $0.7041 \pm 0.0005$ (Sheraton and Black 1981) are also similar to the Cuddapah basin tholeiites (e.g., Crawford and Compston 1973). Igneous activity in the Cuddapah area was at least partly contemporaneous with the igneous activity in the Napier Complex of east Antarctica.

\section{Bulk composition}

The basaltic rocks inside and outside the basin contain a wide range of $\mathrm{MgO}$ (Murty et al 1987; Chatterjee and Bhattacharji 1998). Selected compositions are given in table 2 . The xenolith and xenocryst bearing basalts inside the basin contain 
Table 1(B). Whole rock age of basaltic dikes around the Cuddapah basin, south India.

\begin{tabular}{|c|c|c|c|c|c|}
\hline & Location* & Trend & Age & Method & Source \\
\hline K110 & $\mathrm{N}$ & NE-SW & $1335 \pm 49$ & $\mathrm{~K}-\mathrm{Ar}$ & Murty et al (1987). \\
\hline K34 & W, Dhone & $\mathrm{NE}-\mathrm{SW}$ & $1157 \pm 41$ & $\mathrm{~K}-\mathrm{Ar}$ & Murty et al (1987). \\
\hline K72 & $\begin{array}{l}\text { W, Radial dike, } \\
\text { Dhone }\end{array}$ & NW-SE & $1454 \pm 56$ & $\mathrm{~K}-\mathrm{Ar}$ & Murty et al (1987). \\
\hline K88 & $\begin{array}{l}\text { W, Radial dike, } \\
\text { Dhone }\end{array}$ & NW-SE & $1489 \pm 5$ & ${ }^{40} \mathrm{Ar}-{ }^{39} \mathrm{Ar}$ & This study. \\
\hline K122 & $\mathrm{N}$ & WNW-ESE & $1471 \pm 54$ & $\mathrm{~K}-\mathrm{Ar}$ & Murty et al (1987). \\
\hline K104 & $\mathrm{N}$ & $\mathrm{N}-\mathrm{S}$ & $1384 \pm 13$ & $\mathrm{~K}-\mathrm{Ar}$ & This study. \\
\hline D75 & SW & NE-SW & $1414 \pm 52$ & $\mathrm{~K}-\mathrm{Ar}$ & Murty et al (1987). \\
\hline D28 & SW & NE-SW & $1367 \pm 49$ & $\mathrm{~K}-\mathrm{Ar}$ & Murty et al (1987). \\
\hline D110 & & NE-SW & $1335 \pm 49$ & $\mathrm{~K}-\mathrm{Ar}$ & $\begin{array}{l}\text { Chatterjee and Bhattacharji (under } \\
\text { preparation). }\end{array}$ \\
\hline D49 & SW & NE-SW & $1349 \pm 49$ & $\mathrm{~K}-\mathrm{Ar}$ & $\begin{array}{l}\text { Chatterjee and Bhattacharji (under } \\
\text { preparation). }\end{array}$ \\
\hline D84 & S, Tirupati & ENE-WNW & $1333 \pm 4$ & ${ }^{40} \mathrm{Ar}-{ }^{39} \mathrm{Ar}$ & $\begin{array}{l}\text { Chatterjee and Bhattacharji (under } \\
\text { preparation). }\end{array}$ \\
\hline D9 & & NW-SE & $1203 \pm 47$ & $\mathrm{~K}-\mathrm{Ar}$ & $\begin{array}{l}\text { Chatterjee and Bhattacharji (under } \\
\text { preparation). }\end{array}$ \\
\hline D30 & SW & NW-SE & $1212 \pm 4$ & ${ }^{40} \mathrm{Ar}-{ }^{39} \mathrm{Ar}$ & $\begin{array}{l}\text { Chatterjee and Bhattacharji (under } \\
\text { preparation). }\end{array}$ \\
\hline D89 & S, Tirupati & NW-SE & $1280 \pm 47$ & $\mathrm{~K}-\mathrm{Ar}$ & Murty et al (1987). \\
\hline D77 & SW & NNW-SSE & $1371 \pm 4$ & ${ }^{40} \mathrm{Ar}-{ }^{39} \mathrm{Ar}$ & This study. \\
\hline D76 & SW & $\mathrm{E}-\mathrm{W}$ & $1713 \pm 65$ & $\mathrm{~K}-\mathrm{Ar}$ & Murty et al (1987). \\
\hline D33 & SW & $\mathrm{E}-\mathrm{W}$ & $1250 \pm 38$ & $\mathrm{~K}-\mathrm{Ar}$ & Murty et al (1987) \\
\hline D8A & SW & $\mathrm{E}-\mathrm{W}$ & $1879 \pm 5$ & ${ }^{40} \mathrm{Ar}-{ }^{39} \mathrm{Ar}$ & This study. \\
\hline D11 & & & $1518 \pm 37$ & $\mathrm{~K}-\mathrm{Ar}$ & This study. \\
\hline D88 & S, Tirupati & $\mathrm{E}-\mathrm{W}$ & $1349 \pm 48$ & $\mathrm{~K}-\mathrm{Ar}$ & This study. \\
\hline D86 & S, Tirupati & $\mathrm{E}-\mathrm{W}$ & $1161 \pm 45$ & $\mathrm{~K}-\mathrm{Ar}$ & Murty et al (1987). \\
\hline
\end{tabular}

* For location, see figure 1.

the highest $\mathrm{Mg}$ with $\mathrm{MgO}>20 \mathrm{wt} \%$. Other high$\mathrm{MgO}$ tholeiites outside the basin contain as high as $12 \mathrm{wt} \% \mathrm{MgO}$. A majority of the basalts are tholeiites with $\mathrm{MgO}<8 \mathrm{wt} \%$. About half of the tholeiites outside the basin are olivine-normative. The rest are quartz-normative.

\subsection{Trace element composition}

Basalts from both inside and outside of the basin are enriched in large-ion-lithophile elements (LILE) K, Rb and Ba, whereas, they have similar or slightly depleted concentrations of other incompatible elements compared to MORB (Chatterjee and Bhattacharji 1998, and figure 5). The trace element patterns further indicate that the rocks outside the basin have a higher $\mathrm{Rb}$ content and higher $\mathrm{Zr} / \mathrm{P}$ and $\mathrm{Zr} / \mathrm{Ti}$ than the rocks inside the basin. In general, the rocks outside the basin have lower $\mathrm{Ba} / \mathrm{Rb}, \mathrm{Ti} / \mathrm{Zr}$ and $\mathrm{Ti} / \mathrm{Y}$ and higher $\mathrm{Zr} / \mathrm{Nb}$ and $\mathrm{Y} / \mathrm{Nb}$ than the Cuddapah basin rocks (figure 6). Hofmann and White (1983) have argued that the ratio of very highly incompatible elements such as $\mathrm{Ba}: \mathrm{Rb}$ is constant in tholeiites and their differentiates and reflect the ratio of their mantle source. And Nesbitt and Sun (1976) noted that Ti/Zr, $\mathrm{Ti} / \mathrm{Y}, \mathrm{Zr} / \mathrm{Nb}$ and $\mathrm{Y} / \mathrm{Nb}$ are relatively constant in komatiites from western Australia, Canada and
South Africa indicating their primary character and implying that they are not appreciably altered by metamorphism. It is likely that $\mathrm{Ba}$ and $\mathrm{Rb}$ were mobile during metamorphism. This is the reason we see scatter in the diagrams that involve $\mathrm{Ba} / \mathrm{Rb}$ (figure 6). Despite alteration, $\mathrm{Ba} / \mathrm{Rb}$ of our samples and the Amundsen tholeiites of east Antarctica falls into three broad groups corresponding to the three regions under consideration.

\section{Petrogenesis}

The bulk composition of samples, plotted on a clinopyroxene-plagioclase-olivine (cpx-plag-oliv) pseudoternary diagram according to the method of Grove (1993), shows considerable scatter especially for the samples outside the basin (figure 7). Harker-type variation diagrams with contents of different oxides as a function of the $\mathrm{MgO}$ content also show large scatter (figure 8). Thus, the bulk composition data does not seem to indicate any fractional crystallization relation among the basalts outside the basin. A different picture emerges, however, when the mineral compositions and their textural relationships are considered. Calculated values for the olivine-bulk and augitebulk $\mathrm{K}_{\mathrm{D}}^{\mathrm{Fe}-\mathrm{Mg}}$ 's $\left(=\left[\mathrm{X}_{\mathrm{Fe}}^{\text {mineral }} \cdot \mathrm{X}_{\mathrm{Mg}}^{\mathrm{bulk}}\right] /\left[X_{\mathrm{Mg}}^{\text {mineral }} \cdot \mathrm{X}_{\mathrm{Fe}}^{\text {bulk }}\right]\right)$ 

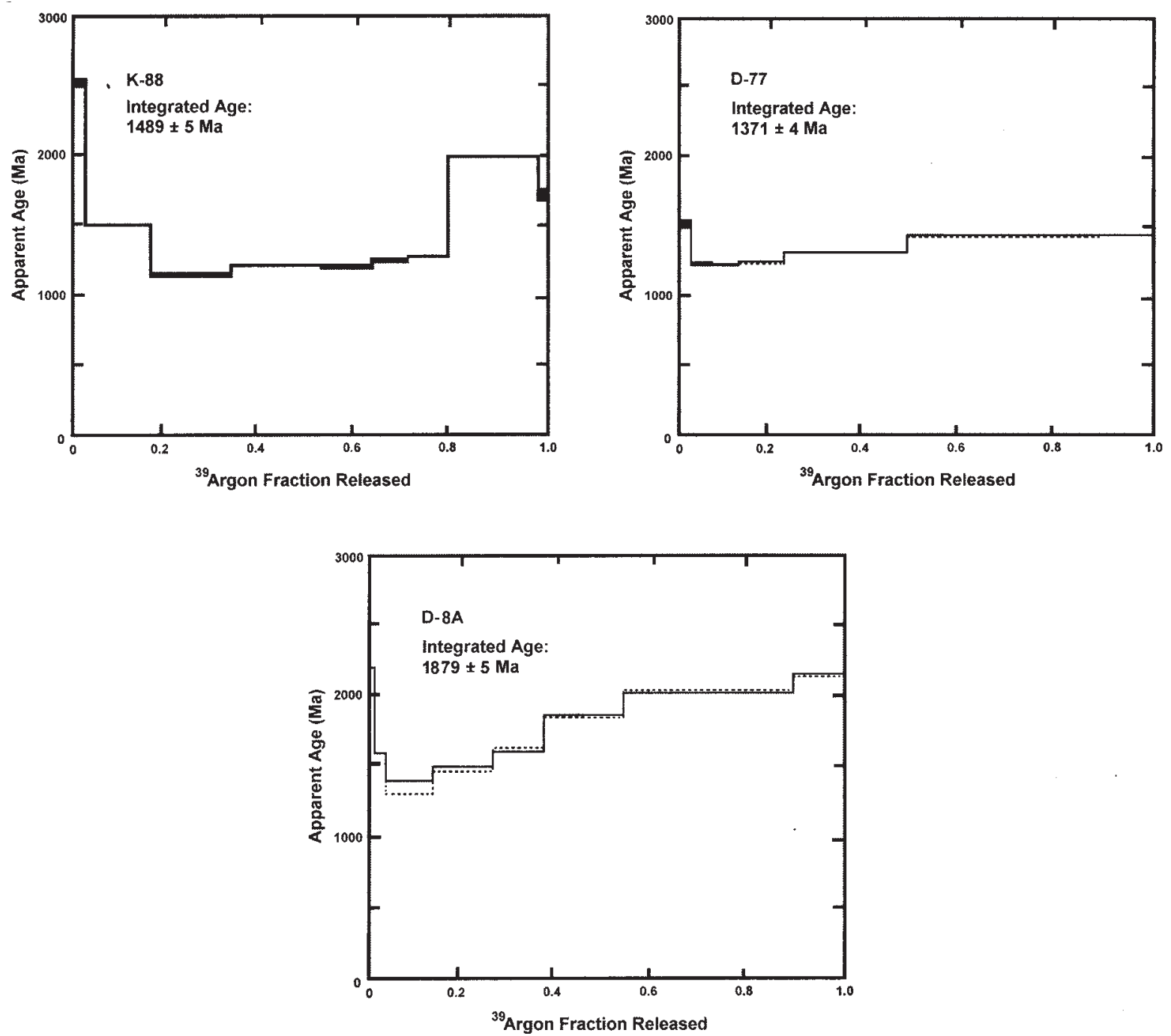

Figure 4. Integrated ${ }^{40} \mathrm{Ar} /{ }^{39} \mathrm{Ar}$ age of NW-SE trending dike K88 from the Dhone radial dike swarm, and NNW-SSE trending dike D77 and E-W trending dike D8A outside the southwest margin of the Cuddapah basin.

and the plagioclase-bulk $\mathrm{K}_{\mathrm{D}}^{\mathrm{Ca}-\mathrm{Na}}\left(=\left[\mathrm{X}_{\mathrm{Ca}}^{\mathrm{plag}} \cdot \mathrm{X}_{\mathrm{Na}}^{\mathrm{bulk}}\right] /\right.$ $\left.\left[\mathrm{X}_{\mathrm{Na}}^{\mathrm{plag}} \cdot \mathrm{X}_{\mathrm{Ca}}^{\mathrm{bulk}}\right]\right)$ from bulk compositions and compositions of olivine, pyroxene and plagioclase (table 3 ) indicate that in most cases, these minerals are not in equilibrium with the bulk rock. For basalts, the equilibrium values of these partition coefficients are $0.3,0.23$ and about 1.5 respectively under low pressure and anhydrous conditions (Sisson and Grove 1993; Grove et al 1997). For the Cuddapah dikes, these values range 0.69-0.85, 0.18-0.54 and 0.54-2.1 respectively (Chatterjee and Bhattacharji, under preparation). Hence, most of these rocks are cumulates. These cumulates, however, show a positive correlation between their plagioclase-Ca\# (atomic $\mathrm{Ca} /[\mathrm{Ca}+\mathrm{Na}]$ in plagioclase) and augite- $\mathrm{Mg} \#$ (atomic $\mathrm{Mg} /[\mathrm{Mg}+\mathrm{Fe}]$ in augite). This indicates that the co-crystallization of plagioclase and augite was important in the formation of these rocks, and they may be related by fractional crystallization.
For the basaltic sills inside the basin, Chatterjee and Bhattacharji (1998) showed that they may be related by fractional crystallization at $5 \mathrm{~kb}$ by calculating a liquid line of descent for the B1 starting composition, according to the method of Grove et al (1992). The same authors also demonstrated that the xenolith-bearing basalts are related to B1 by addition of the xenolithic component to B1. They further observed that the olivines in the xenoliths are similar in composition to calculated olivine compositions in equilibrium with B1 $\left(\mathrm{Fo}_{77.8}\right)$ and $\mathrm{B} 81\left(\mathrm{Fo}_{78.4}\right)$ at $5 \mathrm{~kb}$ and $1142-1154^{\circ} \mathrm{C}$ using Ford et al's (1983) equations after corrections based on Parman et al (1995). A similar temperature range $\left(1019-1148^{\circ} \mathrm{C}\right.$ at $\left.5 \mathrm{~kb}\right)$ was obtained for the equilibration of the xenoliths from twopyroxene thermometry using the equation of Brey and Kohler (1990).

Periodic intrusion by magma along the same conduits and magma mixing is evident in some of the 
Table 2. Chemical composition of basaltic sills and dikes in and around Cuddapah Basin.

\begin{tabular}{|c|c|c|c|c|c|c|c|c|c|c|}
\hline $\begin{array}{l}\text { Sample } \\
\text { Rock } \\
\text { Location } \\
\text { Dike/Sill }\end{array}$ & $\begin{array}{c}\text { B1 } \\
\text { thol } \\
\text { inside } \\
\text { sill }\end{array}$ & $\begin{array}{c}\text { B81 } \\
\text { thol } \\
\text { inside } \\
\text { sill }\end{array}$ & $\begin{array}{c}\text { B37 } \\
\text { thol } \\
\text { inside } \\
\text { sill }\end{array}$ & $\begin{array}{c}\text { M3 } \\
\text { thol } \\
\text { inside } \\
\text { sill }\end{array}$ & $\begin{array}{c}\mathrm{J} 4 \\
\text { thol } \\
\text { out } \\
\text { dike }\end{array}$ & $\begin{array}{c}\mathrm{K} 104 \\
\text { hi-Mg } \\
\text { out } \\
\text { dike }\end{array}$ & $\begin{array}{c}\text { D30A } \\
\text { hi-Mg } \\
\text { out } \\
\text { dike }\end{array}$ & $\begin{array}{c}\text { D75A } \\
\text { thol } \\
\text { out } \\
\text { dike }\end{array}$ & $\begin{array}{c}\mathrm{D} 84 \mathrm{~A} \\
\text { hi-Mg } \\
\text { out } \\
\text { dike }\end{array}$ & $\begin{array}{c}\text { D89A } \\
\text { thol } \\
\text { out } \\
\text { dike }\end{array}$ \\
\hline \multicolumn{11}{|c|}{ Weight per cent } \\
\hline $\mathrm{SiO}_{2}$ & 45.99 & 48.39 & 50.39 & 49.79 & 51.40 & 53.09 & 48.97 & 49.61 & 53.87 & 48.12 \\
\hline $\mathrm{TiO}_{2}$ & 1.66 & 1.03 & 1.52 & 1.46 & 0.66 & 0.64 & 0.54 & 1.60 & 0.65 & 1.05 \\
\hline $\mathrm{Al}_{2} \mathrm{O}_{3}$ & 15.02 & 16.59 & 13.36 & 14.73 & 15.69 & 13.22 & 14.90 & 14.42 & 14.59 & 15.82 \\
\hline $\mathrm{Fe}_{2} \mathrm{O}_{3}{ }^{*}$ & 7.65 & 5.04 & 9.10 & 15.59 & 3.12 & 4.99 & 3.59 & 7.00 & 1.55 & 5.94 \\
\hline $\mathrm{FeO}$ & 10.27 & 9.40 & 7.50 & n.d. & 7.28 & 7.69 & 7.70 & 10.19 & 9.93 & 8.64 \\
\hline $\mathrm{MnO}$ & 0.22 & 0.17 & 0.26 & 0.17 & 0.16 & 0.16 & 0.18 & 0.22 & 0.07 & 0.19 \\
\hline $\mathrm{MgO}$ & 7.90 & 7.10 & 5.63 & 5.34 & 7.80 & 9.52 & 11.19 & 4.20 & 8.22 & 7.23 \\
\hline $\mathrm{CaO}$ & 8.74 & 9.36 & 9.03 & 9.48 & 9.88 & 7.69 & 10.33 & 9.47 & 7.60 & 9.22 \\
\hline $\mathrm{Na}_{2} \mathrm{O}$ & 1.70 & 1.96 & 2.66 & 2.49 & 2.97 & 1.47 & 2.07 & 2.49 & 2.08 & 2.26 \\
\hline $\mathrm{K}_{2} \mathrm{O}$ & 0.61 & 0.76 & 0.32 & 1.36 & 0.88 & 1.32 & 0.49 & 0.62 & 1.35 & 1.41 \\
\hline $\mathrm{P}_{2} \mathrm{O}_{5}$ & 0.24 & 0.20 & 0.23 & 0.36 & 0.15 & 0.22 & 0.05 & 0.18 & 0.08 & 0.11 \\
\hline $\mathrm{FeO}^{* *}$ & 17.16 & 13.93 & 15.69 & 14.03 & 10.09 & 12.18 & 10.93 & 16.50 & 11.32 & 13.98 \\
\hline $\mathrm{M}^{\prime}$ & 45.06 & 47.59 & 39.00 & 40.42 & 57.95 & 58.23 & 64.60 & 31.20 & 56.42 & 47.95 \\
\hline \multicolumn{11}{|c|}{ Weight ppm } \\
\hline $\mathrm{Ba}$ & 212 & 181 & 81 & 148 & n.d. & 161 & 58 & 205 & 147 & 196 \\
\hline $\mathrm{Rb}$ & 17 & 29 & 7 & 37 & 35 & 61 & 38 & 18 & 121 & 61 \\
\hline $\mathrm{Nb}$ & 5 & 4 & 8 & 6 & n.d. & n.d. & n.d. & n.d. & 6 & 6 \\
\hline $\mathrm{Sr}$ & 198 & 141 & 279 & 47 & 303 & 132 & 149 & 100 & 163 & 307 \\
\hline $\mathrm{Zr}$ & 103 & 71 & 114 & 83 & 182 & 147 & 115 & 135 & 159 & 157 \\
\hline $\mathrm{Y}$ & 22 & 17 & 25 & 17 & 27 & 34 & 29 & 27 & 30 & 37 \\
\hline $\mathrm{Co}$ & n.d. & n.d. & n.d. & n.d. & 47 & 48 & 58 & 88 & 43 & 59 \\
\hline $\mathrm{Cr}$ & n.d. & n.d. & n.d. & n.d. & 57 & 473 & 1036 & 69 & 496 & 296 \\
\hline $\mathrm{Cu}$ & 206 & 65 & 199 & 91 & 19 & 115 & 103 & 138 & 99 & 200 \\
\hline $\mathrm{Ni}$ & 163 & 155 & 57 & 104 & 48 & 171 & 313 & 70 & 184 & 203 \\
\hline $\mathrm{V}$ & n.d. & n.d. & n.d. & n.d. & n.d. & 292 & 282 & 311 & 284 & 270 \\
\hline $\mathrm{Zn}$ & 110 & 81 & 111 & 84 & n.d. & 105 & 45 & 200 & 41 & 114 \\
\hline
\end{tabular}

- Concentrations are determined by XRF except $\mathrm{Fe}_{2} \mathrm{O}_{3}$ and $\mathrm{FeO}$, which are determined by wet chemical techniques.

- The major oxide concentrations are normalized to a sum of 100 ; where FeO is not available, $50 \%$ of $\mathrm{Fe}_{2} \mathrm{O}_{3}$ is considered as $\mathrm{FeO}$ in normalization calculation.

- thol: tholeiite; hi-Mg: high-MgO tholeiites; n.d.: not determined; $\mathbf{M}^{\prime}=$ atomic $100 \times \mathrm{Mg} /(\mathrm{Mg}+\mathrm{Fe})$. Location refers to inside or outside the basin; for precise locations, refer to figure 2.

- ${ }^{*}$ reported as total $\mathrm{Fe}_{2} \mathrm{O}_{3}$ where $\mathrm{FeO}$ data are not available; ${ }^{* *}$ total $\mathrm{FeO}$.

cross cutting dikes outside the southwestern margin of the Cuddapah Basin (Chatterjee and Bhattacharji, under preparation). Dike intrusion into a pre-existing long fracture or lineament (deepseated fault or plane of weakness in the crust) usually occurs at the time of reactivation of the lineament. Comparison of relative ages and compositional relationships of cross cutting dikes, therefore, reflects not only the petrogenesis of these dikes, but also the relative time of crustal extension with reactivation of major lineaments, especially if they intrude over a long distance paralleling the lineament trends.

At the southwestern margin of the basin, where the oldest sedimentary formation of the Cuddapah basin was deposited, there are two prominent crosscutting tholeiitic dikes (D28 and D30) which trend parallel to the NE-SW and NW-SE lineaments of the Dharwar Archean crust respectively. The tholeiitic dike D28, dated at $1367 \pm 49 \mathrm{Ma}$ (table $1 \mathrm{~B})$, is a prominent geomorphic feature, occurring as prominent ridges and extending over $20 \mathrm{~km}$ in the NE-SW direction from the basin margin. This dike is segmented and the segments occur in an en echelon pattern. Cutting across this dike is another tholeiitic dike, D30, which is dated at $1212 \pm 4 \mathrm{Ma}$ (table 1B) and also occurs as segmented dike ridges paralleling the major NW-SE lineament. In the olivine-tholeiite dike D28, a vein of magma different in composition from the bulk is found to intrude the host dike. Dike D30, which cross cuts D28, contains $\mathrm{Mg}$-poor resorbed orthopyroxenes surrounded by a higher-Mg overgrowth rim and rhythmically zoned plagioclase (figure 9) strongly indicating that magma mixing was important in its formation. The rationale behind selectively studying these two major dikes at the southwestern margin of the Cuddapah basin is that the time of intrusion or emplacement of these two cross cutting dikes should indicate the relative time of crustal extension associated with the initial development of the Cuddapah basin. 

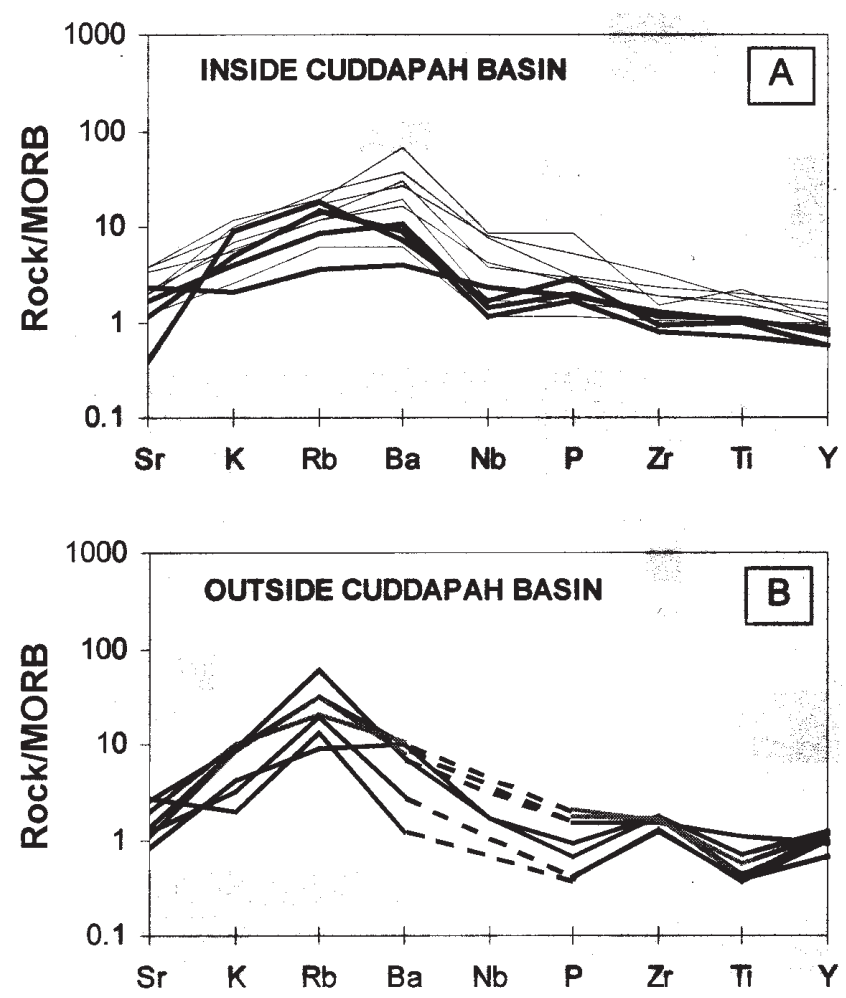

Figure 5. MORB normalized (according to Pearce 1983) incompatible trace element contents of tholeiite sills within Cuddapah basin (A) and outside the basin (B). Amundsen tholeiites from Napier Complex, east Antarctica (Sheraton and Black 1981) are also shown in thin lines in (A).

\section{Discussion}

Bhattacharji (1987) noted an episodic igneous activity in the form of dike intrusions in the Dharwar Archean basement over a period between 2400 and $650 \mathrm{Ma}$ on the basis of thirteen $\mathrm{K}$-Ar age determinations (one by Balasubrahmanyan 1975) and two Rb-Sr ages determined by Ikramuddin and Stueber (1976). Available radiometric ages of mafic dikes around the margin of the Cuddapah basin and the eastern Dharwar craton suggest at least three major episodes of dike intrusive activity during 1900-1700 Ma, 1500-1300 Ma and 1200-640 Ma respectively (Padmakumari and Dayal 1987; Mallikharjuna Rao et al 1995; Sarkar and Mullik 1995). Paleomagnetic studies confirm these three separate periods of dike emplacement (Kumar and Bhalla 1983; Hargraves and Bhalla 1987). Ages of several mafic dikes along the NE-SW and NW-SE lineaments outside the basin (1500-1200 Ma, table 1B), the Dhone radial dike swarm west of the basin (1500-1400 Ma, table 1B) and the Chelima lamproite dikes near the center of the basin (1300-1400 Ma, table 1A) fall in the second of the three periods mentioned above. It is postulated that these dikes owe their origin to a deep mantle perturbation, which is manifested by the funnel shaped lopolithic intrusion in the southwestern part of the present day basin. Thus, it seems that the mantle perturbation, which is believed to have started at the onset of basin evolution, was a constant thermal source between 1500 and $1200 \mathrm{Ma}$, leading to crustal dilation, lineament reactivation and igneous intrusive activity.

It must be mentioned here that all available $\mathrm{K}-\mathrm{Ar}$ and $\mathrm{Rb}-\mathrm{Sr}$ age dates, including from this study, have large uncertainties. ${ }^{40} \mathrm{Ar}-{ }^{39} \mathrm{Ar}$ dates have lower uncertainties, but the ${ }^{39} \mathrm{Ar}$ release spectra do not show plateaus (figure 4). Both K-Ar and ${ }^{40} \mathrm{Ar}-{ }^{39} \mathrm{Ar}$ dates are susceptible to errors due to the problems of Ar loss. Rb-Sr systems have also been known to reset during metamorphism. The ${ }^{39} \mathrm{Ar}$ release spectrum of K88 shows a prominent saddle (figure 4). Saddles can occur in a spectrum in different ways. The initial high ${ }^{39} \mathrm{Ar}$ release is normally attributed to degassing of altered/weathered minerals in the initial heating step. The large release of ${ }^{39} \mathrm{Ar}$ in one of the last steps may be due to trapped $\mathrm{Ar}$ in anionic sites of feldspars, which require high temperatures to be released (Professor Kip Hodges, MIT, personal communication, 2000). D8A shows a step-like increase in ${ }^{39} \mathrm{Ar}$ production with temperature (figure 4). This can happen either by postcrystallization Ar loss due to metamorphism, or by very slow cooling of the rock, whereby, Ar remains near the cores of minerals, but diffuses out from grain boundaries (Hodges, personal communication, 2000). If the higher temperatures reflect the actual age of formation, the age of D8A will be pushed back slightly. Indeed, an initial K-Ar age determination of D8A yielded 1938 Ma. Keeping in mind the large uncertainties in the age dates, we are presenting a plausible model for the evolution of the Cuddapah basin.

The radiometric ages of the NW-SE and NE-SW trending dikes in the southern and southwestern regions outside the Cuddapah basin (figure 1, table $1 \mathrm{~B}$ ) indicate that the lineaments along these directions were intensely reactivated between 1400 and $1200 \mathrm{Ma}$ during the evolution of the Cuddapah basin. Petrographic evidence of lineament reactivation is preserved in some of the cross-cutting dikes of this region. These reactivations were in the form of dilation along the NW-SE and NE-SW directions leading to channeling of magma in these preferred directions. The later intrusions gave rise to cross cutting relationships between these dikes and the dikes from the earlier intrusions. Dike D28, which is cross-cut by the younger dike D30, preserves interesting petrographic evidence of renewed magmatic activity along the directions of the two major lineaments.

Mass balance calculations in the reaction zone surrounding the vein in D28 indicate that $38 \%$ of the vein reacted with $62 \%$ of the host dike. If the 

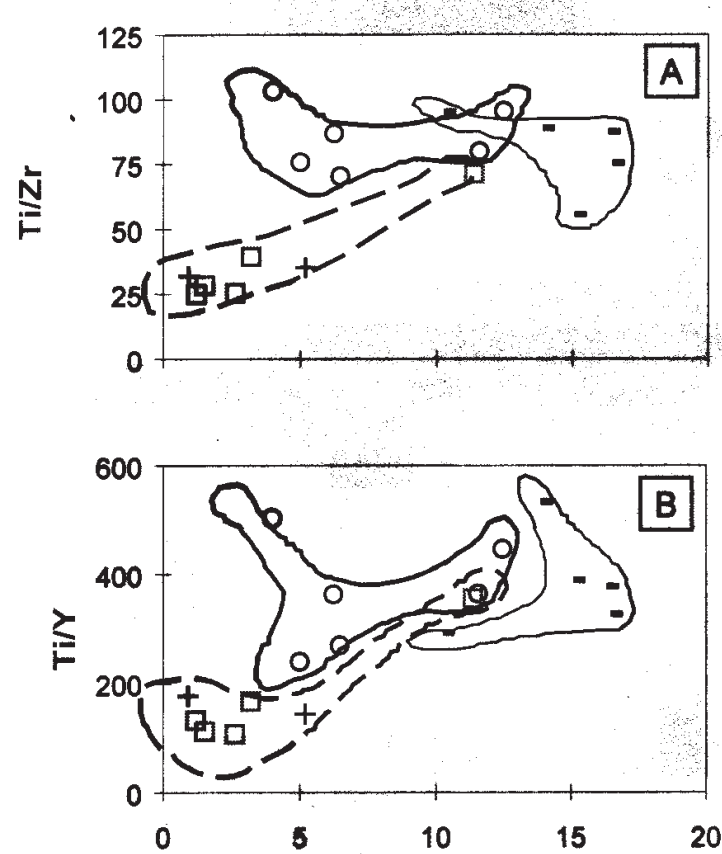

$\mathrm{Ba} / \mathrm{Rb}$

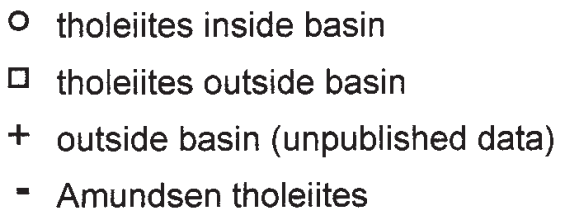

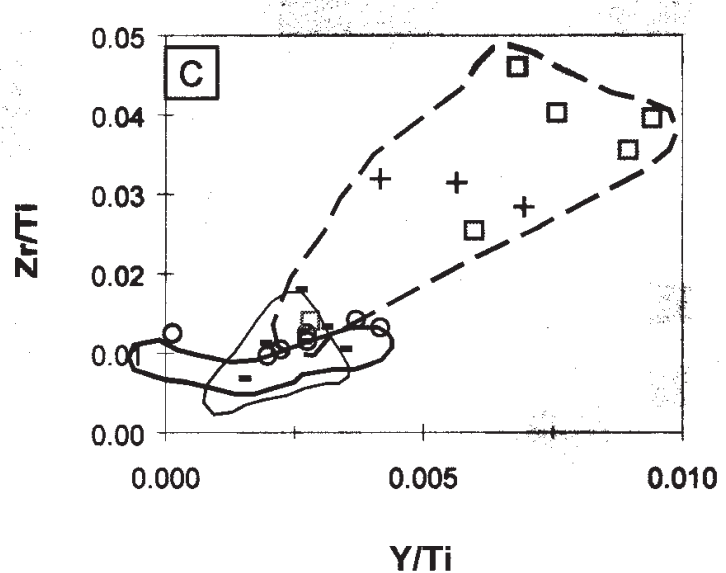

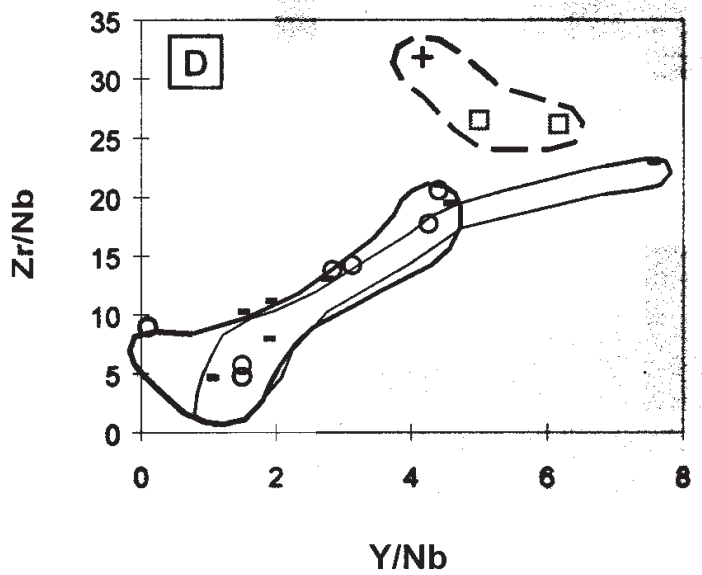

Figure 6. Variation of (A) Ti/Zr and (B) Ti/Y with Ba/Rb; (C) Zr/Ti with Y/Ti; and (D) Zr/Nb with Y/Nb. Symbols are as follows: open circles: Cuddapah basin basalts, squares and plusses: basalts outside the basin, and dashes: Amundsen tholeiites from east Antarctica (Sheraton \& Black 1981). The boundary around the Cuddapah basin basalts is in bold line; around the basalts outside the basin, in dashed line; and around the Amundsen tholeiites, in thin line.

liquid in equilibrium with the core of the relict orthopyroxenes in D30 is mixed in a 0.65:0.35 proportion with the vein material of $\mathrm{D} 28$, the resulting liquid will be in equilibrium with the $\mathrm{Mg}$ rich overgrowth rim of the orthopyroxenes of D30 (Chatterjee and Bhattacharji, under preparation). This indicates that chemically similar liquids interacted with an older solidified rock (D28), which was intruded, and a younger magma undergoing crystallization (D30), whose compostion was altered by the process of magma-mixing.

The dense lopolithic intrusion beneath the southwest region of the basin is indicated by the seismic profiles of Kaila et al (1979), gravity anomaly maps of Balakrishna (1979) and Grant (1983), and magnetic anomaly data of Murty et al (1987). Bhattacharji (1987) postulated that an asthenospheric upwelling and diapiric rise of magma with excess magma pressure gave rise to the cupola or funnel shaped intrusion into the upper levels of the crust (figure 3 of Bhattacharji 1987). The magma cupola was postulated as the proximal source for emplacement of sills, dikes and lava flows around and within the basin. Bulk composition of the sills and composition of the minerals in the xenoliths indicate that the tholeiites in the cupola originated at a temperature of $1019-1154^{\circ} \mathrm{C}$ and a depth of about $18 \mathrm{~km}$ (Chatterjee and Bhattacharji 1998). The cupola may have served as a site for fractional crystallization. Fractionated melts possibly rose to the surface to form concentric sill intrusions along the periphery of the lopolithic cupola. Crystal fractionation products possibly settled along the wall of the cupola. Sills containing fractionated crystals (the xenolith bearing sills) are thus located at the outermost periphery.

\subsection{Trace element implications}

Basalts both inside and outside the basin are enriched in $\mathrm{Ba}, \mathrm{Rb}$ and $\mathrm{K}$ compared to MORB (figure 5). Sheraton and Black (1981) found evidence of a Ba-Rb-K-Th-rich fluid that enriched the source of some of the Amundsen tholeiites. A similar metasomatic enrichment may have occurred 


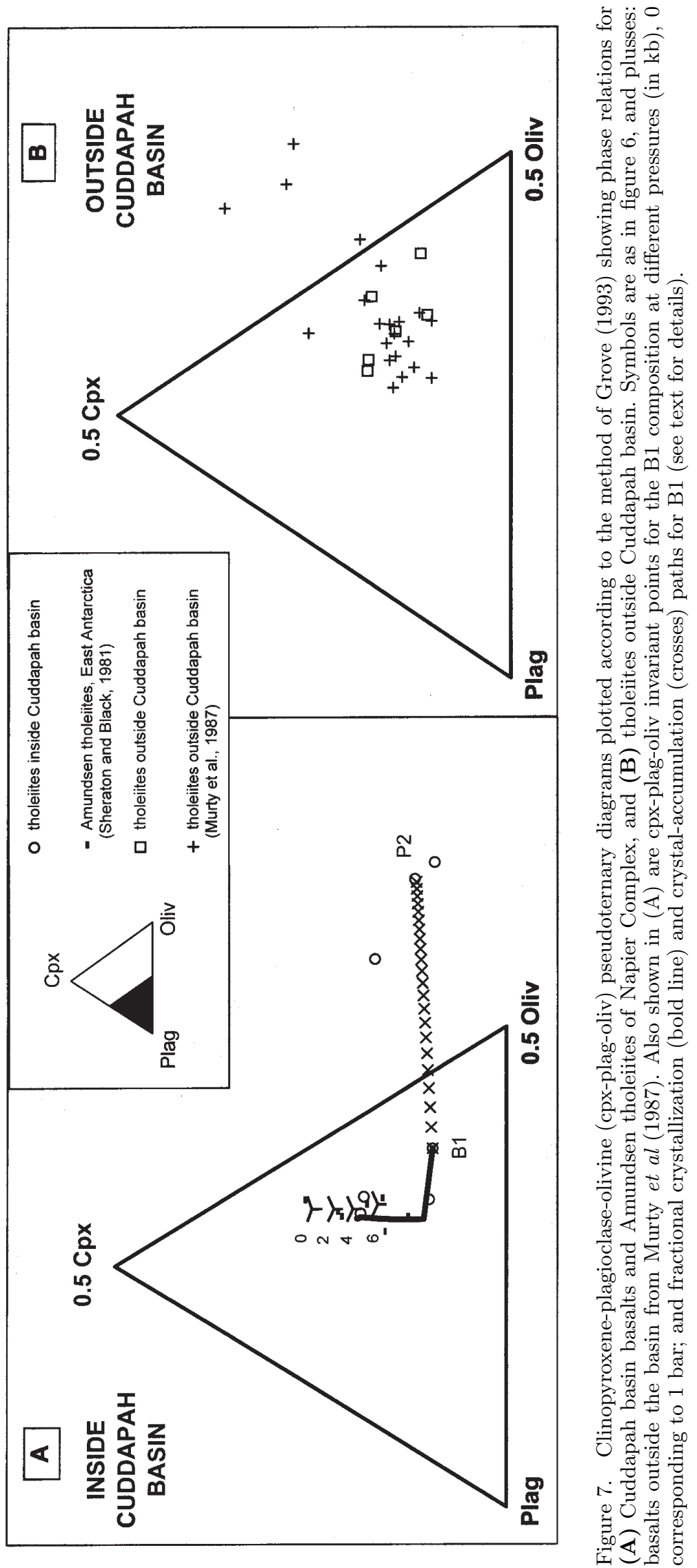



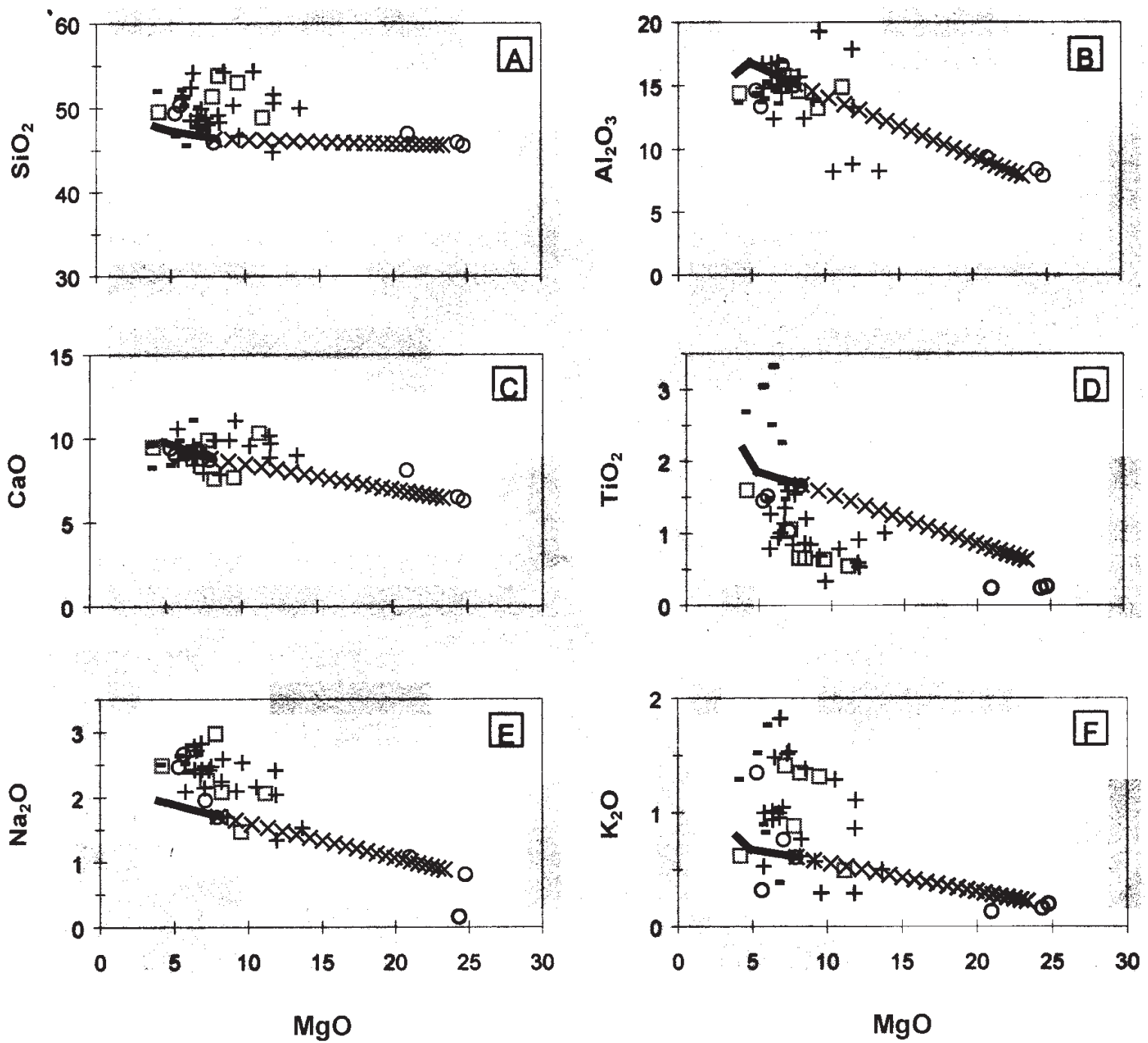

Figure 8. Variation of different oxides with MgO. Symbols, and fractionation and accumulation paths are as in figure 7.

in the Cuddapah area. Higher ${ }^{87} \mathrm{Sr} /{ }^{86} \mathrm{Sr}$ in the younger tholeiites (0.7041-0.7044) than the older ones $(0.7012-0.7020)$ in south India and east Antarctica (Crawford and Comspton 1973; Ikramuddin and Stueber 1976; Sheraton and Black 1981) may reflect contributions from $\mathrm{Rb}$ to the ${ }^{87} \mathrm{Sr}$ content in a Rb-enriched mantle as time progressed. This metasomatic enrichment of the mantle may have been widespead on a global scale. In addition to east Antarctica, Marsh et al (1992) found evidence of metasomatic enrichment in the Proterozoic Klipriviersberg tholeiites $(\sim 2.7 \mathrm{Ga})$ of the Kaapvaal craton of South Africa, which was a part of the Proterozoic Gondwanaland. These tholeiites contain similar amounts of $\mathrm{Ba}, \mathrm{Rb}$ and $\mathrm{K}$ to the Cuddapah tholeiites. In figure 10 , the MORB-normalized incompatible trace elements of Proterozoic basalts are plotted. The $2.7 \mathrm{Ga}$ and younger basalts include the Cuddapah tholeiites (both inside and outside the basin), the Napier Complex tholeiites and high-Mg basalts, and the Klipriviersberg tholeiites. The Kolar basalts (about
$80 \mathrm{~km}$ south of Cuddapah basin, see figure 2), which are about $2.9 \mathrm{Ga}$ (Bhalla et al 1978, as in Rajamani et al 1985), show lower contents of Ba, $\mathrm{Rb}$ and $\mathrm{K}$. We can thus conclude that the metasomatic event may have occurred between $\sim 2.9$ and $2.7 \mathrm{Ga}$.

There is local heterogeneity in the mantle as indicated by different $\mathrm{Zr} / \mathrm{Ti}, \mathrm{Y} / \mathrm{Ti}, \mathrm{Zr} / \mathrm{Nb}$ and $\mathrm{Y} / \mathrm{Nb}$ inside and outside the Cuddapah basin (figure 6). We also see different ranges of values for $\mathrm{Ba} / \mathrm{Rb}$ in the regions outside Cuddapah basin, inside Cuddapah basin and the Napier Complex area (figure 6). There is also evidence of major element heterogeneity in the mantle in the region outside Cuddapah basin. Rajamani et al (1985) concluded that the mantle source for the Kolar komatiitic amphibolites have a higher Fe content than pyrolite (proposed by Ringwood 1975). On the other hand, mantle composition at VajrakarurLattavaram (west of Cuddapah basin, figure 1), calculated from mineral compositions (Ganguly and Bhattacharya 1987) and modes in garnet 
Table 3. Sample mineral compositions of the dikes around Cuddapah basin measured by electron microprobe.

\begin{tabular}{|c|c|c|c|c|c|c|}
\hline & $\begin{array}{l}\text { D84 } \\
\text { plag } \\
\text { core }\end{array}$ & $\begin{array}{l}\text { D30 } \\
\text { plag } \\
\text { core }\end{array}$ & $\begin{array}{l}\text { D84 } \\
\text { aug } \\
\text { core }\end{array}$ & $\begin{array}{l}\text { D30 } \\
\text { aug } \\
\text { core }\end{array}$ & $\begin{array}{l}\text { D30 } \\
\text { opx } \\
\text { relict }\end{array}$ & $\begin{array}{c}\text { D30 } \\
\text { opx } \\
\text { overgrowth }\end{array}$ \\
\hline $\mathrm{SiO}_{2}$ & 53.00 & 49.77 & 52.38 & 53.03 & 54.12 & 54.67 \\
\hline $\mathrm{TiO}_{2}$ & - & - & 0.44 & 0.13 & 0.22 & 0.11 \\
\hline $\mathrm{Al}_{2} \mathrm{O}_{3}$ & 29.48 & 31.57 & 2.23 & 2.14 & 1.62 & 1.86 \\
\hline $\mathrm{Cr}_{2} \mathrm{O}_{3}$ & - & - & 0.12 & 1.18 & 0.49 & 0.68 \\
\hline $\mathrm{FeO}$ & 0.95 & 0.51 & 12.55 & 5.56 & 12.70 & 9.82 \\
\hline $\mathrm{MnO}$ & - & - & 0.30 & 0.20 & 0.28 & 0.25 \\
\hline $\mathrm{MgO}$ & 0.16 & 0.21 & 16.63 & 19.99 & 28.44 & 30.27 \\
\hline $\mathrm{CaO}$ & 12.70 & 13.86 & 16.17 & 18.08 & 2.29 & 2.49 \\
\hline $\mathrm{Na}_{2} \mathrm{O}$ & 4.27 & 3.25 & 0.23 & 0.21 & 0.03 & 0.01 \\
\hline $\mathrm{K}_{2} \mathrm{O}$ & 0.16 & 0.14 & - & - & - & - \\
\hline Total & 100.71 & 99.31 & 101.06 & 100.53 & 100.19 & 100.18 \\
\hline $\mathrm{Si}$ & 2.396 & 2.286 & 1.933 & 1.921 & 1.936 & 1.931 \\
\hline $\mathrm{Ti}$ & - & - & 0.012 & 0.004 & 0.006 & 0.003 \\
\hline $\mathrm{Al}$ & 1.571 & 1.709 & 0.097 & 0.092 & 0.069 & 0.078 \\
\hline $\mathrm{Cr}$ & - & - & 0.004 & 0.034 & 0.014 & 0.019 \\
\hline $\mathrm{Fe}$ & 0.036 & 0.020 & 0.387 & 0.169 & 0.380 & 0.290 \\
\hline Mn & - & - & 0.009 & 0.006 & 0.009 & 0.008 \\
\hline $\mathrm{Mg}$ & 0.011 & 0.015 & 0.915 & 1.079 & 1.516 & 1.594 \\
\hline $\mathrm{Ca}$ & 0.615 & 0.682 & 0.639 & 0.702 & 0.088 & 0.094 \\
\hline $\mathrm{Na}$ & 0.374 & 0.290 & 0.017 & 0.015 & 0.002 & 0.001 \\
\hline K & 0.009 & 0.008 & - & - & - & - \\
\hline Oxygen & 8 & 8 & 6 & 6 & 6 & 6 \\
\hline Cations & 5.011 & 5.009 & 4.013 & 4.02 & 4.018 & 4.018 \\
\hline En or An & 0.62 & 0.70 & 0.47 & 0.55 & 0.76 & 0.81 \\
\hline Fs or $\mathrm{Ab}$ & 0.37 & 0.30 & 0.33 & 0.09 & 0.19 & 0.15 \\
\hline $\mathrm{Mg} \#$ or $\mathrm{Ca \#}$ & 0.62 & 0.70 & 0.70 & 0.86 & 0.80 & 0.85 \\
\hline Bulk Rock Mg\# or Ca\# & 0.67 & $0.73-0.71$ & $0.56-0.48$ & $0.65-0.53$ & & \\
\hline $\mathrm{K}_{\mathrm{D}}^{\mathrm{Fe}-\mathrm{Mg}}$ or $\mathrm{K}_{\mathrm{D}}^{\mathrm{Ca}-\mathrm{Na}}$ & 1.24 & $1.13-1.03$ & $0.54-0.39$ & $0.29-0.18$ & & \\
\hline
\end{tabular}

- $\mathrm{Mg} \#=$ atomic $\mathrm{Mg} /(\mathrm{Mg}+\mathrm{Fe}), \mathrm{Ca} \#=$ atomic $\mathrm{Ca} /(\mathrm{Ca}+\mathrm{Na})$.

- $\operatorname{aug}=$ augite, plag = plagioclase, opx = orthopyroxene.

- $\mathrm{Mg} \#$ applies to augite and orthopyroxene, Ca\# applies to plagioclase.

- $\mathrm{K}_{\mathrm{D}}^{\mathrm{Fe}-\mathrm{Mg}}$ calculated for augite-bulk, $\mathrm{K}_{\mathrm{D}}^{\mathrm{Ca}-\mathrm{Na}}$ calculated for plag-bulk (see text for explanation).

lherzolite xenoliths (worldwide average, suggested by Maaloe and Aoki 1977) shows a higher $\mathrm{MgO}$ (43.95 wt\%) and lower FeO (6.69wt\%) content than pyrolite.

Although the mantle under the Proterozoic Gondwanaland was locally heterogeneous, there is no evidence of large-scale differences as found during the Jurassic period. Geochemical studies on Jurassic Gondwana flood basalts in Parana (Bellieni et al 1984, 1986; Mantovani et al 1985; Fodor 1987), Karoo (Cox et al 1967) and Etendeka (Duncan 1987; Marsh 1987) have revealed a northern high $\mathrm{P}_{2} \mathrm{O}_{5}-\mathrm{TiO}_{2}$ (HPT) region and a southern low $\mathrm{P}_{2} \mathrm{O}_{5}-\mathrm{TiO}_{2}$ (LPT) region. The boundary between the two regions may be stretched to the Ferrar province of southeast Australia-Antarctica (Hergt et al 1991). The differences between the two regions have been attributed to different mantle source compositions and crustal contamination. The Cuddapah tholeiites are all LPT basalts. The older Kolar basalts (Rajamani et al 1985) are also low $\mathrm{TiO}_{2}$ basalts $\left(\mathrm{P}_{2} \mathrm{O}_{5}\right.$ data unavailable). The Klipriviersberg tholeiites (Marsh et al 1992) are also LPT basalts. On the other hand, both LPT and HPT basalts are present in east Antarctica (Sheraton and Black 1981). Thus, it appears that the Jurassic LPT-HPT regimes did not exist during the Proterozoic time period under consideration.

\section{Conclusion}

Precursors to the evolution of the Cuddapah basin may be traced back to about $2400 \mathrm{Ma}$ when the first basaltic dikes were emplaced in the south Indian shield. E-W trending dikes were emplaced in the west of the present-day basin beginning at about 1900 Ma. The first igneous activity began inside the basin in the form of lava flows seems to have begun at about $1850 \mathrm{Ma}$, although the actual age remains uncertain. Mantle upwelling resulting in the emplacement of a lopolithic magma cupola in the present day southwestern region of the Cuddapah basin, evident from a positive gravity anomaly, may have happened at the onset of the Cuddapah basin evolution. This deep mantle pertur- 


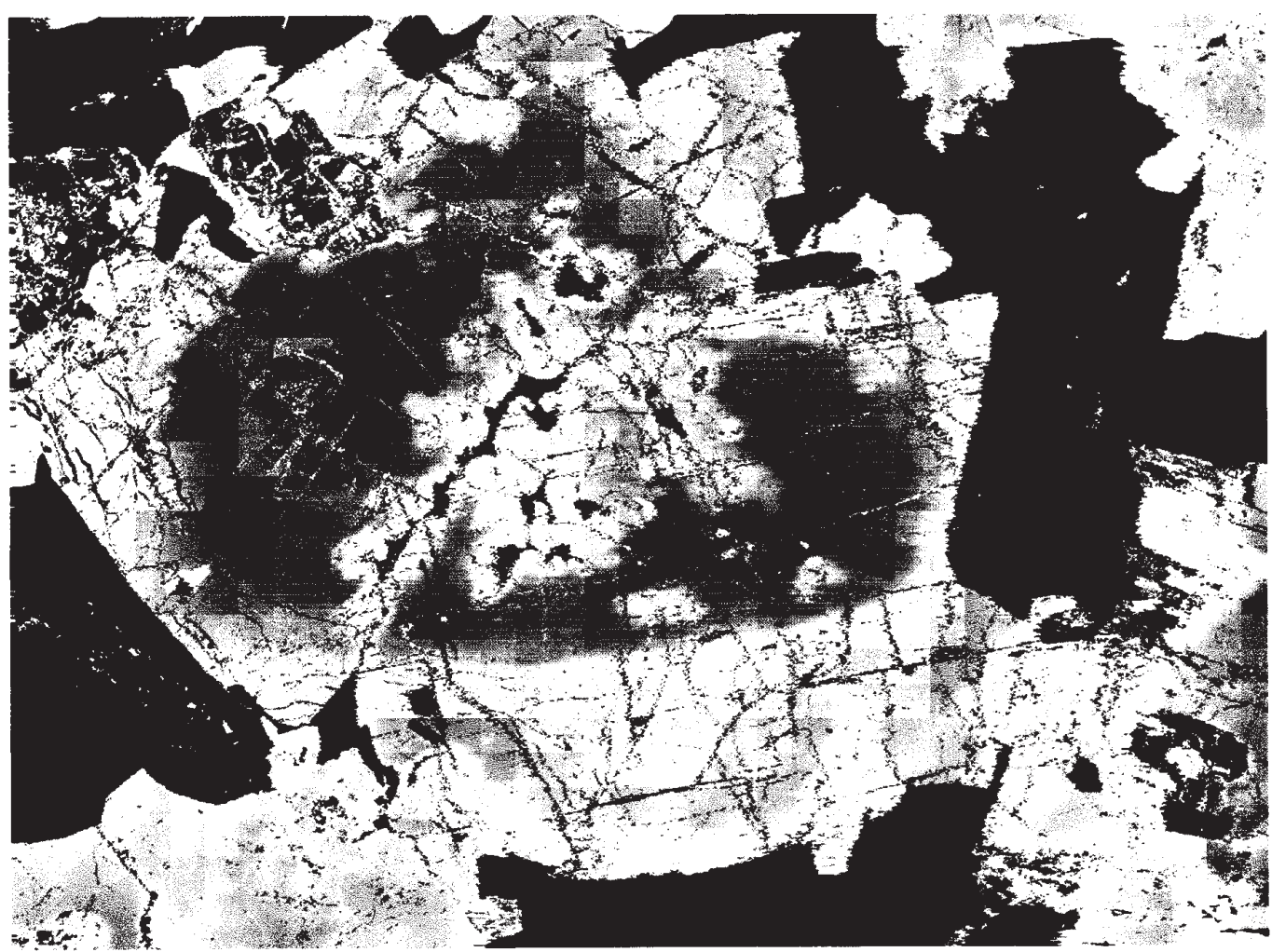

Figure 9. Backscattered electron images of a cross-section of a large grain of orthopyroxene surrounded by grains of plagioclase in dike D30. The width of the image is $4 \mathrm{~mm}$. The orthopyroxene contains a relict grain at the center and a thick overgrowth showing Fe-Mg zoning with Fe increasing toward the periphery. The relict is richer in Fe than the overgrowth in the immediate vicinity.

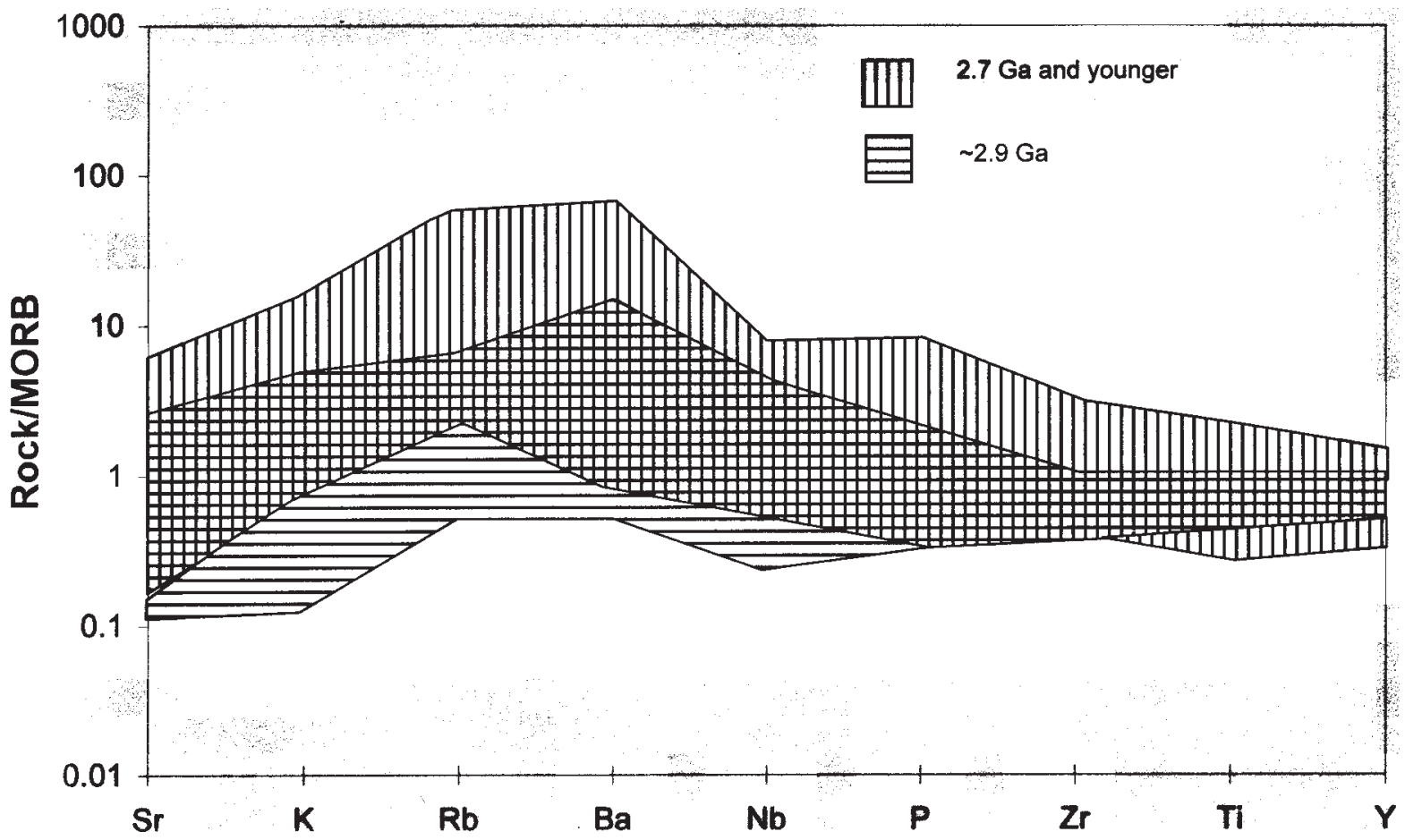

Figure 10. MORB normalized (according to Pearce 1983) concentration ranges of incompatible trace elements of 2.7 Ga and younger (vertically lined-area), and $\sim 2.9 \mathrm{Ga}$ (horizontally lined-area) Proterozoic Gondwana tholeiites and high-MgO basalts. Data for $2.7 \mathrm{Ga}$ and younger basalts are from this study, Sheraton \& Black (1981, for Napier complex tholeiites and high-MgO basalts) and Marsh et al (1992, for Klipriviersberg tholeiites); and for 2.9 Ga, from Rajamani et al (1985, for Kolar basalts). 
bation played an important role in the development of the basin, as it was a constant thermal source responsible for dike and sill emplacement between 1500 and $1200 \mathrm{Ma}$ both inside and outside the basin. Lineament reactivation in the NW-SE and NE-SW directions intensified between 1400 and $1200 \mathrm{Ma}$, leading to the emplacement of several cross cutting dikes.

$\mathrm{Fe}-\mathrm{Mg}$ and $\mathrm{Ca}-\mathrm{Na}$ partition coefficients of olivine, augite and plagioclase, calculated from the composition of these minerals and the bulk composition of their host rocks indicate that the dikes outside the Cuddapah basin are cumulates. The contemporary dikes may be related by fractional crystallization as indicated by a positive correlation between their plagioclase $\mathrm{Ca \#}$ and augite $\mathrm{Mg} \#$. NW-SE and NE-SW cross cutting dikes of this period preserve petrographic evidence of episodic magmatic intrusive activity along preferred directions possibly in response to lineament reactivation that led to the evolution of the Cuddapah basin. Petrological reasoning indicates that similar magmatic liquids reacted with a set of cross cutting dikes, intruding into one that was already solidified and altering the composition of the magma that produced the other dike.

Igneous activity continued intermittently throughout and possibly after the deposition of the Cuddapah sediments inside and outside the basin. This included the emplacement of alkali syenite and granite bodies and the Chelima lamproite dikes within the Nallamalai sediments near the center of the basin, younger sills in the Tadpatri formation, and granophyre dikes outside the basin. The Chelima lamproite dikes, which are dated at about $1400 \mathrm{Ma}$, place an upper bound on the age of the Cuddapah sequence. If these ages are true indications, the entire Cuddapah sequence was laid down between approximately 1850 and $1400 \mathrm{Ma}$. Intrusive activity, however, continued after sedimentation ceased until about $800 \mathrm{Ma}$. The Lower Cuddapah tholeiites may be related by fractional crystallization at $5 \mathrm{~kb}$ and $1019-1154^{\circ} \mathrm{C}$. The xenolith bearing picrites originated by the accumulation of xenoliths in the other tholeiites as indicated by the composition of the olivine in the xenoliths of the picritic sills $\left(\mathrm{FO}_{78.7-81.9}\right)$, which are closely similar to calculated olivine compositions $\left(\mathrm{Fo}_{77.8-78.3}\right)$ in equilibrium with the tholeiites under the same $P-T$ conditions. Fractionation of the tholeiites thus occurred at a depth of about $18 \mathrm{~km}$ in the lopolithic cupola. The fractionated crystals may have settled on the walls of the cupola. As a result the xenolith-bearing sills occur at the periphery of the lopolithic body.

Compared to MORB, the tholeiites both inside and outside the basin are enriched in $\mathrm{K}, \mathrm{Ba}$ and
$\mathrm{Rb}$ and similar in $\mathrm{P}, \mathrm{Zr}$, Ti and $\mathrm{Y}$. The $\mathrm{Ba}$, $\mathrm{Rb}$ and $\mathrm{K}$ contents of $\sim 2.4 \mathrm{Ga}$ Bidadi-Harohalli tholeiites (south India) and high-Mg east Antarctic tholeiites, $\sim 2.9 \mathrm{Ga}$ Kolar tholeiites (south India) and $\sim 2.7 \mathrm{Ga}$ Klipriviersberg tholeiites of South Africa indicate that a widespread metasomatic enrichment of the mantle source may have occurred in Proterozoic Gondwana between $\sim 2.9$ and $\sim 2.7 \mathrm{Ga}$. The basalts inside the Cuddapah basin have a different trace element signature than the basalts outside the basin, which may be attributed to small-scale local mantle heterogeneity. The Cuddapah basin tholeiites have higher $\mathrm{Ba} / \mathrm{Rb}, \mathrm{Ti} / \mathrm{Zr}, \mathrm{Ti} / \mathrm{Y}$ and lower $\mathrm{Zr} / \mathrm{Nb}$ and $\mathrm{Y} / \mathrm{Nb}$ than the tholeiites outside the basin. Large-scale differences such as the low $\mathrm{P}_{2} \mathrm{O}_{5}-\mathrm{TiO}_{2}$ and high $\mathrm{P}_{2} \mathrm{O}_{5}-\mathrm{TiO}_{2}$ basaltic domains of the Jurassic Gondwana basalts, however, did not exist during the Proterozoic time period under consideration.

\subsection{Future research}

In establishing the tectonomagmatic history in the evolution of the Cuddapah basin, several intriguing and puzzling questions remain to be answered. Why did such intense magmatic activities occur within and around a prototype Proterozoic basin on the south Indian lithosphere, while such magmatic activities were limited and negligible in other adjacent basins during the same period? Further tectonic and geophysical study is required to find out if magmatism has indeed been negligible in the other basins. A more puzzling question is, how can such a prolonged period of magmatic activities, though episodic, be sustained over a period of almost a billion years? Even if one invokes a stationary or shifting mantle plume underneath the south Indian lithosphere, what could be the thermomechanical condition of the mantle and the south Indian lithosphere in late Archean-Proterozoic time which allowed deep mantle rejuvenation and mantle perturbation to produce episodic magmatic activities? Without much needed precise geochronological and paleomagnetic data, answer to such fundamental questions would remain conjectural and speculative.

Proterozoic rocks may suffer repeated thermal metamorphism and alteration during their long history, which may affect their radioactive systems commonly used in age dating. Both the K-Ar and ${ }^{40} \mathrm{Ar}-{ }^{39} \mathrm{Ar}$ methods may yield uncertain ages due to Ar loss. The Rb-Sr method is also known to reset during thermal metamorphism. The U-Pb zircon method is promising. This method, along with borehole stratigraphy, has been successfully applied to determine the age of the Klipriviersberg tholeiites of South Africa (references within Marsh et al 1992). Initial scans of dike samples by the first 
author of this study yielded very small grains of baddeleyite and zircon (5-10 microns) in the Cuddapah rocks. It is a daunting task to isolate these grains from the samples for mass spectrometry. But future research should focus in this direction.

\section{Acknowledgement}

We thank Professor J Ganguly of University of Arizona, Professor T L Grove of MIT, Dr. H Yoder of Geophysical Laboratory, Carnegie Institution of Washington and two anonymous reveiwers for their valuable comments and suggestions during the preparation of the manuscript. Professor Grove also provided the computer programs for phase equilibrium calculations, for which we are very grateful. Age dating was done in U.S. and Canadian laboratories under a UNDP support to NGRI, Hyderabad, India, where the second author was a consultant and participant in the Cuddapah basin project. S B thanks the retired Director of NGRI, Dr. D. Guptasharma, for making the data available, and the Director and Librarian of Geophysical Laboratory, Carnegie Institution of Washington for making the library facilities available. Part of the study was financially supported by a Faculty Research Grant (RF6-68585) of the City University of New York to S B.

\section{References}

Artyushkov E V, Schlesinger A E and Yanshin A L 1980 The origin of vertical crustal movements within lithospheric plates. In: Dynamics of Plate Interiors, Washington DC: Geodynamics, AGU Publ., (eds.) A W Balley, P L Bender, T R McGetchin, and R I Walcott, (eds.) 1 37-51

Balakrishna S, Paul P A and Ramana Rao A V 1972 Gravity and magnetic investigation in south-western region of Cuddapah Basin. Geophys. Res. Bull. 10 92-104

Balakrishna S 1979 Some recent geophysical studies in the Cuddapah basin, Proceedings of 3rd Workshop on Status, Problems and Programmes in Cuddapah Basin. - 22-32, Hyderabad, A.P., India (Inst. Indian Penn. Geol. Publ.)

Balakrishna S, Venkatanarayana B, Venkateshwara Rao 1983 Geological and geophysical investigations along a few selected east-west traverses across the south-western margin of the Cuddapah Basin. In: S Bhattacharji and S Balakrishna (eds.), Evolution of the intracratonic Cuddapah Basin, South India, Monograph 2, Inst. Ind. Penn Geol. Publ., Hyderabad, A.P., India, 19-46

Balakrishna S, Krishna Brahman N and Sarma J R K 1984 Salient features of the New Bouger Gravity Map of the Cuddapah basin on IGSN71 and GRS67. Workshop on Purana Basins (Middle to Late Proterozoic of Peninsular India), Hyderabad, India

Balasubramanyan M N 1975 The age of the dykes of South Canara, Mysore State. Geol. Surv. India, Misc. Publ. 23 236-239

Bellieni G, Brotzu P, Comin-Chiaramonti P, Ernesto M, Melfi A, Pacca I G and Piccirillo E M 1984 Flood basalts to rhyolite suites in southern Parana Plateau (Brazil): paleomagnetism, petrogenesis and geodynamic implications; J. Petrology 25 579-618
Bellieni G, Comin-Chiaramonti P, Marques L S, Melfi A J, Nardy A J R, Papatrechas C, Piccirillo E M, Roisenberg A and Stolfa D 1986 Petrogenetic aspects of acid and basaltic lavas from the Parana Plateau (Brazil): geological, mineralogical and petrological relationships; $J$. Petrology 27 915-944

Beloussov, V V 1960 Development of the earth and tectogenesis; - J. Geophys. Res. 76 1197-1211

Bhalla N S, Gupta J M, Tikam Chabria and Vasudeva S G 1978 Rb-Sr geochronology of rocks from the Kolar schist belt, south India. In: Archean Geochemistry. (eds.) B F Windley, and S M Naqvi, - 79-84; (Amsterdam: Elsevier Scientific Publishing Co.).

Bhaskar Rao Y J, Pantulu G V C, Damodara Reddy V and Gopalan K 1995 Time of early sedimentation and volcanism in the Proterozoic Cuddapah basin, south India: evidence from the Rb-Sr age of Pulivendla mafic sill; $\mathrm{Mem}$. Geol. Soc. India 33 329-338

Bhattacharji S 1981 Evolution of an intracratonic basin. (ed.) S. Balakrishna, (ed.) In: Evolution of an intracratonic Cuddapah basin; Inst. Ind. Penn. Geol. Publ., Hyderabad, A. P., India, Monograph 1 7-28

Bhattacharji S and Singh R N 1984 Thermomechanical structure of the southern part of the Indian shield and its relevance to Precambrian basin evolution; Tectonophys. $105103-120$

Bhattacharji S 1986 Asthenospheric upwelling, lineament reactivation, magmatic episodes and ore mineralization in Proterozoic Cuddapah Basin evolution on the Archean Indian shield. Int. Basement Tectonic Associations; 5 $183-200$

Bhattacharji S 1987 Lineaments and igneous episodes in the evolution of intracratonic Proterozoic basins on the Indian Shield. - (ed.) A K Saha, In: Geological evolution of Peninsular India - petrological and structural aspects; Recent Researches in Geology 13 1-15

Bott M H P 1978 Subsidence mechanism at passive continental margins; Amer. Assoc. Petrol. Geol. Mem. 29 3-9

Brey G P and Kohler T 1990 Geothermobarometry in fourphase lherzolites II. New thermobarometers, and practical assessment of existing thermobarometers; J. Petrology, 31 1353-1378

Chalapathi Rao N V, Miller J A, Pyle D M and Madhavan V 1996 New Proterozoic K-Ar ages for some kimberlites and lamproites from the Cuddapah basin and Dharwar craton, south India: evidence for non-contemporaneous emplacement; Precamb. Res. 79 363-369

Chalapathi Rao N V, Miller J A, Gibson S A, Pyle D M and Madhavan V 1999 Precise ${ }^{40} \mathrm{Ar} /{ }^{39} \mathrm{Ar}$ age determinations of the Kotakonda kimberlite and Chelima lamproite, India: implication to the timing of mafic dike swarm emplacement in the eastern Dharwar craton; $J$. Geol. Soc. India 53 425-432

Chatterjee N and Bhattacharji S 1998 Formation of Proterozoic tholeiite intrusives in and around Cuddapah Basin, south India and their Gondwana counterparts in east Antarctica: and compositional variation in their mantle sources; N. Jb. Miner. Abh. 174/1 79-102

Chatterjee $\mathrm{N}$ and Bhattacharji $\mathrm{S}$ (under preparation): Petrology and geochemistry of the Proterozoic dikes and sills in and around Cuddapah Basin, south India: comparison with Proterozoic intrusives in other parts of the world.

Collerson K D and Sheraton J W 1986 Age and geochemical characteristics of a mafic dike swarm in the Archean Vestfold Block, Antarctica: inferences about Proterozoic dike emplacement in Gondwana; J. Petrology 27 853-886 
Cox K G, Macdonald R and Hornung G 1967 Geochemical and petrographic provinces in the Karoo basalts of southern Africa; Amer. Mineralogy 52 1451-1474

Crawford A R and Compston W 1973 The age of the Cuddapah and Kurnool systems, south India; J. Geol. Soc. Australia 19 453-464

Dalziel I W D 1991 Pacific margins of Laurentia and east Antarctica-Australia as a conjugate rift pair: evidence and implications for an Eocambrian supercontinent; Geology 19 598-601

Dasgupta P K 1986 Picrite borne mantle xenoliths from Cuddapah Basin, south India; Indian J. Earth Science $13333-338$

Dayal A M and Padmakumari V M 1985 K-Ar ages of Dolerite Dykes from Southwest margin of Cuddapah Basin: Presented at the 3rd National Symposium on Mass Spectrometry, Hyderabad, India.

Duncan A R 1987 The Karoo igneous province - a problem area for inferring tectonic setting from basalt geochemistry; J. Volcanology Geotherm. Res. 32 13-34

Embleton B J J 1984 Continental paleomagnetism. (ed.) J J Veevers, In: Phanerozoic earth history of Australia, Oxford Geol. Sci. Series No.2. - 17-38, Oxford (Clarendon Press).

Falvey D A 1974 The development of continental margins in plate tectonic theory; J. Aust. Petrol. Explor. Assoc. 14 95-106

Fodor R V 1987 Low- and high- $\mathrm{TiO}_{2}$ flood basalts of southern Brazil; origin from picritic parentage and a common mantle source. Earth and Planetary Science Letters 84(4) 423-430

Ford C E, Russell D G, Craven J A and Fisk M R 1983 Olivine-liquid equilibria: temperature, pressure and composition dependence of the crystal/liquid cation partition coefficients for $\mathrm{Mg}, \mathrm{Fe}^{2+}, \mathrm{Ca}$ and $\mathrm{Mn} ;$ J. Petrology 24 $256-265$

Ganguly J and Bhattacharya P K 1987 Xenoliths in Proterozoic kimberlites from southern India: petrology and geophysical implications. (ed.) P.H. Nixon, In: Mantle xenoliths. - 349 p. (New York : John Wiley and Sons).

Grant F S 1983 Results of the preliminary interpretation studies. In: Report on a visit to NGRI, Hyderabad, India. - Project IND/79047, Sep-Oct, 1983 (unpubl.), 5-17

Grove T L, Kinzler R J and Brown W B 1992 Fractionation of mid-ocean ridge basalt (MORB). In: Mantle flow and melt generation at mid-oceanic ridges; Geophysical Monograph 71 (Amer. Geophys. Union,) 281-310

Grove T L 1993 Corrections to expressions for calculating mineral components in "Origin of calc-alkaline series lavas at Medicine Lake volcano by fractionation, assimilation and mixing" and "Experimental petrology of normal MORB near the Kane fracture zone: $22^{\circ}-25^{\circ} \mathrm{N}$, midAtlantic ridge"; Contrib. Mineralogy Petrology 114422 424

Grove T L, Donnelly-Nolan J M and Housh T 1997 Magmatic processes that generated the rhyolite of Glass Mountain, Medicine Lake volcano, N. California; Contrib. Mineral. Petrol. 127 205-223

Hargraves R B and Bhalla M S 1983 Precambrian paleomagnetism in India through 1982, a review; Geol. Soc. India Mem. 4 491-524

Haxby W F, Turcotte D L and Bird J M 1976 Thermal and mechanical evolution of the Michigan Basin; Tectonophys. 36 57-75

Hergt J M, Peate D W and Hawkesworth C J 1991 The petrogenesis of Mesozoic Gondwana low-Ti flood basalts; Earth Planet. Sci. Lett. 105 134-148

Hoffman P F 1991 Did the breakout of Laurentia turn Gondwanaland inside-out? Science 252 1409-1412
Hofmann A W and White W M 1983 Ba, Rb and Cs in the earth's mantle; Z. Naturforsch 38a 256-66

Ikramuddin M and Stueber A M 1976 Rb-Sr ages of Precambrian dolerite and alkaline dikes, southeast Mysore state, India; Lithos 9 235-241

Johnson B D and Veevers J J 1984 Oceanic paleomagnetism. (ed.) J J Veevers, In: Phanerozoic earth history of Australia, Oxford Geol. Sci. Series No.2 17-38, Oxford (Clarendon Press).

Kaila K L, Murty P R K and Mall D M 1979 The evolution of the Vindhyan Basin vis-a-vis the Narmada-Son lineament, central India, from, Deep Seismic Sounding; Tectonophys. 162 277-289

Kaila K L and Tewari H C 1983 Structure and tectonics of the Cuddapah basin in the light of DSS studies. In: Evolution of the Intracratonic Cuddapah Basin, SouthIndia, S. Bhattacharii and S. Balakrishna (eds.) Inst. Ind. Penn. Geol. Publ., Hyderabad, A. P., India, Monograph 2 53-62

Kumar A and Bhalla M S 1983 Paleomagnetics and igneous activity of the area adjoining the southwestern margin of the Cuddapah basin, India; Geophys. Jour. Royal Astro. Soc. 73 27-37

Kumar A, Sivaraman T V, Bhaskar Rao, Y J and Gopalan K 1990 Rb-Sr age of two dike swarms from the Dharwar craton, Karnataka. Int. Symp: Structure and Dynamics of the Indian lithosphere. (Hyderabad, India, Feb. 1989), Abstract.

Kumar A, Bhaskar Rao Y J, Padmakumari V M, Dayal A M and Gopalan K 1988 Late Cretaceous mafic dikes in the Dharwar craton; Proc. Indian Acad. Sci. (Earth Planet. Sci.) 97(I) 107-114

Maaloe S and Aoki K 1977 The major element composition of the upper mantle estimated from the composition of lherzolites; Contrib. Mineralogy Petrology 63 161-173

Mantovani M S M, Marques L S, DeSousa M A, Civetta L, Atalla L and Innocenti F 1985 Trace element and strontium isotope constraints on the origin and evolution of Parana continental basalts of Santa Catarina State (Southern Brazil); J. Petrology 26 187-209

Mallikharjuna Rao J, Bhattacharji S, Rao M M and Hermes O D $1995{ }^{40} \mathrm{Ar} /{ }^{39} \mathrm{Ar}$ ages and geochemical characteristics of dolerite dikes around the Proterozoic Cuddapah basin, South India; Mem. Geol. Soc. India 33 307-328

Marsh J S 1987 Basalt geochemistry and tectonic discrimination within continental flood basalt provinces; J. Volcanology Geotherm. Res. 32 35-49

Marsh J S, Bowen M P, Rogers N W and Bowen T W 1992 Petrogenesis of late Archean flood-type basic lavas from the Klipriviersberg Group, Ventersdorp Supergroup, South Africa; J. Petrology 33 817-847

McKenzie D 1978 Some remarks on the development of sedimentary basins; Earth Planet. Sci. Lett. 40 25-32

Murthy N G K 1964 The traps and dolerites in the Cuddapah basin; J. Geol. Science Association 4 79-88

Murthy Y G K 1979 Geology of the Cuddapah basin-a review, In: Proceedings of 3rd Workshop on 'Status, Problems and Programmes in Cuddapah Basin'. - 1-21 Hyderabad, A.P., India (Inst. Indian Penn. Geol. Publ.)

Murthy Y G K, Babu Rao V, Guptasarma D, Rao J M, Rao M N and Bhattacharji S 1985 Tectonic and petrochemical significance and geophysical studies of mafic dyke swarms around the Proterozoic Cuddapah Basin, South India. Int. Conf. Mafic Dyke Swarms (Abst. vol.). Univ. Toronto. Canada: 111-113

Murthy Y G K, Babu Rao V, Guptasarma D, Rao J M, Rao M N and Bhattacharji S 1987 Tectonic, petrochemical and geophysical studies of mafic dike swarms around the Proterozoic Cuddapah basin, South India; In: Mafic 
dyke swarms (eds) H.C. Halls, and W.F. Fahrig, Geol. Association Canada Special Paper 34 303-316

Nesbitt R W and Sun S S 1976 Geochemistry of Archean spinifex-textured peridotites and magnesian and lowmagnesian tholeiites; Earth Planet Sci. Letters 31 433453

Parman S, Grove T L, Dann J and deWit M 1995 Quantitative estimates of the chemical composition and liquidus temperatures of komatiite magmas from the Barberton Mountainland, South Africa; EOS, Amer. Geophys. Union Spring Meet. Abstracts 76/17 S297

Padmakumari V M and Dayal A M 1987 Geochronological studies of some mafic dikes around the Cuddapah basin, south India; Mem. Geol. Soc. India 6 369-374

Pearce J A 1983 The role of sub-continental lithosphere in magma genesis at destructive plate margins. (eds) C J Hawkesworth, and M J Norry, In: Continental basalts and mantle xenoliths. - 230-249 Natwich (Shiva).

Piper J D A 1987 Paleomagnetism and the continental crust. - 434 p., Milton Keynes (Open University Press)

Rajamani V, Shivkumar K, Hanson G N and Shirey S B 1985 Geochemistry and petrogenesis of amphibolites, Kolar schist belt, south India: evidence for komatiitic magma derived by low percentages of melting of the mantle; J. Petrology 26 92-123

Rao M N and Rao S V L N 1964 Study of contact metamorphism associated with some basic sills intrusive into lower Cuddapah rocks; J. Indian Geoscience Association 4 69-74

Rao B V, Rao M G and Raju P R 1979 Some results on the gravity-magnetic investigations in the regions of DSS profile across Cuddapah Basin. In: Proc. 3rd Workshop on 'Status, Problems and Programmes in Cuddapah Basin'. Inst. Ind. Penn. Geol. (IIPG), Hyderabad, A.P., 44-46

Ringwood A E 1975 Composition and petrology of the Earth's mantle. - 618 p., (New York : McGraw-Hill).
Sankarnarayan P V, Paul P A, Sarma S V S, Harinarayana T and Virupakshi G 1979 Telluric field investigations in the south-western region of Cuddapah Basin - preliminary results. In: Proc. 3rd Workshop on 'Status, Problems and Programmes in Cuddapah Basin'. Inst. Ind. Penn. Geol. (IIPG), Hyderabad, A.P., 72-81

Sarkar A and Mullik A K 1995 Geochronology and geochemistry of Precambrian mafic dikes from Kolar Gold Field, Karnataka; Mem. Geol. Soc. India 33 111-132

Sheraton J W and Black L P 1981 Geochemistry and geochronology of Proterozoic tholeiitic dikes of east Antarctica: evidence for mantle metasomatism; Contrib. Mineralogy Petrology 78 305-317

Sheridan R E 1969 Subsidence of continental margins; Tectonophys. 7 219-29

Sinha R C and Krishna Rao M 1968 Geochemistry of basic rocks around Pulivendla, Andhra Pradesh; J. Geochem. Soc. India 3 25-52

Sisson T W and Grove T L 1993 Experimental investigations of the role of water in the calc-alkaline differentiation and subduction zone magmatism; Contrib. Mineral. Petrol. $113143-166$

Sleep N H, Nunn J A and Lei Chou 1980 Platform basins. Ann. Rev. Earth Planet Sci. 8 17-34

Smith A G and Hallam A 1970 The fit of the southern continents; Nature 225 139-144

Somayajulu J G and Singhal B B S 1968 Petrochemistry of basic rocks from Pulivendla, Cuddapah District, A.P. J. Geochem. Soc. India 3 75-84

Steckler M S and Watts A B 1978 Subsidence of the Atlantic type margin off New York. Earth Planet. Sci. Lett. 41 $1-15$

Sundaram R K, Swaminath J and Venkatesh V 1964 Tectonics of Peninsular India. Internat. Geol. Cong. 22nd., New Delhi, 4 539-56

Watts A B and Ryan W B F 1976 Flexure of the lithosphere and continental margin basins; Tectonophys. 36 25-44 